\title{
Impact of Risk-Taking on Firm Value
}

\author{
Yong Jae Shin ${ }^{1} \&$ Unyong Pyo ${ }^{2}$ \\ ${ }^{1}$ Associate Professor, Department of Business Administration, Hankyong National University, Anseong, South \\ Korea \\ ${ }^{2}$ Associate Professor of Finance, Department of Finance, Operations, and Information Systems, Goodman School of \\ Business, Brock University, St. Catharines, Canada \\ Correspondence: Unyong Pyo, Associate Professor of Finance, Department of Finance, Operations, and Information \\ Systems, Goodman School of Business, Brock University, St. Catharines, ON, Canada, L2S3A1. Tel: 905-688-5550, \\ x3147. E-mail: upyo@brocku.ca
}

Received: September 15, 2021

Accepted: October 17, 2021

Online Published: October 25, 2021

doi:10.5430/ijfr.v12n5p223

URL: https://doi.org/10.5430/ijfr.v12n5p223

\begin{abstract}
This paper investigates the relationship between managerial risk-taking and firm value as measured by Tobin's Q. We conduct OLS regressions to examine the relationship between firm value and managerial risk-taking. To consider differential behaviors by different levels of risk-taking, we conduct separate tests on different risk-taking levels and on a dummy variable for risk-taking. We also adjust for industry fixed effects and address potential endogeneity issues with a two-stage least square (2SLS) approach. We find that risk-taking is positively related to firm value, and that this relationship is driven mainly by firms with relatively higher levels of risk-taking. We confirm the findings with various sub-periods, with industry fixed effects, and with two-stage linear regressions. Finally, we show that excessive risk-taking is not value-destroying. Subsequent tests report that higher risk-taking manifests as positive but slightly reduced capital allocation efficiency. When managers engage in more risk-taking, they increase the efficiency of capital allocation, suggesting that both immediate payoffs as well as long-term gains contribute to the boost in firm value. While the prior studies examine managerial risk-taking, none of them explicitly investigate its relation to a variable of particular importance to shareholders: firm value measured as Tobin's Q. Furthermore, prior studies do not examine whether high levels of risk-taking can lead to the acceptance of negative NPV investments and consequently destroy firm value.
\end{abstract}

Keywords: managerial risk-taking, Tobin's Q, corporate governance, firm value

JEL codes: G32, G34

\section{Introduction}

Managerial risk-aversion has been described as "one of the most important underlying variables in all of economics" (Byrd, Parrino, and Pritsch, 1998) due to its far-reaching impacts on a firm's long-term direction and viability. Prior literature establishes that ceteris paribus, managers are inherently risk-averse due to their typically undiversified positions and their natural interests in their own private benefits (Hirshleifer and Thakor, 1992; John, Litov, and Yeung, 2008). As a result, they may forgo potentially profitable projects that they deem too risky, thereby failing to maximize shareholder value. A common response by shareholders and boards is to implement corporate governance and/or compensation contracts to mitigate this risk-aversion. Managerial risk-taking has been subject to the scrutiny of shareholders, boards, and academics due to its implications for firm performance.

Prior studies present ample evidence that shareholders prefer greater managerial risk-taking. John, Litov, and Yeung (2008) find that stronger corporate governance leads to increased risk-taking, which in turn leads to greater asset and sales growth. Faccio, Marchica, and Mura (2011) find evidence that large diversified shareholders can more effectively assert their will and induce managers to take more risk. Conversely, other studies find that some managers may engage in excessive risk-taking, either to maximize their own private payoffs (Dong, Wang, and Xie, 2010) or to try and meet some predetermined performance targets (Van Wesep and Wang, 2014). While all of the prior studies examine managerial risk-taking, none of them explicitly investigate its relation to a variable of particular importance to shareholders: firm value measured as Tobin's Q. Furthermore, prior studies do not examine 
whether high levels of risk-taking can lead to the acceptance of negative NPV investments and consequently destroy firm value.

The current paper aims to fill this gap. Using data for a sample of US public firms during 1961-2015, we conduct OLS regressions to examine the relationship between firm value as measured by Tobin's $\mathrm{Q}$ and managerial risk-taking both for the entire period and for different sub-periods. To consider differential behaviors by different levels of risk-taking, we conduct separate tests on different risk-taking levels and on a dummy variable for risk-taking. We also adjust for industry fixed effects. We address potential endogeneity issues with a two-stage least square (2SLS) approach. We also examine the impacts of corporate governance on firm value. Finally, we investigate how the efficiency of capital allocation is affected by managerial risk-taking.

We find that managerial risk-taking is positively related to firm value. If a firm with the median Tobin's Q increases its risk-taking by one standard deviation, it significantly lifts its firm value measured as Tobin's Q by $79 \%$. These positive relations are mostly confined to firms with levels of high risk-taking. Furthermore, we show that this relation remains positive for firms that take the most risk; there is no evidence that such firms engage in "excessive" risk-taking and destroy firm value. Reviewing the results in different sub-periods, we find that the relations are positive during 1981-2010 and insignificant for the other periods. We confirm the same findings from conducting 2SLS regressions. On the other hand, we find no evidence that corporate governance mechanisms have material impacts on firm value. Finally, we find that high risk-taking is associated with slightly reduced but efficient capital allocation. It appears that when managers engage in more risk-taking, they increase the efficiency of capital allocation, suggesting that both immediate payoffs as well as long-term gains contribute to the boost in firm value.

This study contributes to the literature in three ways. First, we empirically establish that managerial risk-taking is a determinant of firm value. We also extend the literature on risk-taking incentives. Several papers examine the effect of risk-taking incentives, usually in the form of stock option compensation, that focus on the variable vega, defined as the sensitivity of CEO (chief executive officer, hereafter manager) wealth to stock return volatility due to their option holdings. While vega has been empirically linked to greater managerial risk-taking (Coles, Daniels, and Naveen, 2006; Low 2009), our findings build upon the prior studies by showing that the increased risk-taking, in turn, enhances firm value, thus providing support for the merits of stock option compensation. Second, this study does not support the findings of John et al. (2008), who find that stronger investor protection leads to increased managerial risk-taking, possibly due to governance structures which ensure that managers act more in line with shareholder interests. Finally, we show that risk-taking increases the efficiency of capital allocation. In addition, this study finds no evidence that risk-taking is "excessive", suggesting that shareholders might need not concern themselves with tempering risk-taking.

The remainder of this paper is organized as follows. Section 2 provides a review of the literature and a development of the research hypotheses. Section 3 explains the data and methodology adopted in the study. Results are presented in Section 4, while we conclude in Section 5.

\section{Literature Review and Hypotheses}

Managers have a certain degree of risk-aversion that will affect their decisions about corporate investment and strategy. By selecting projects with appropriate levels of risk and potential earnings, managers directly influence the future profitability and competitiveness of their firms. However, concerns arise when the optimal risk profile of the manager is different from that of the shareholders. This differential risk preference is an issue that is closely tied to the agency conflict between managers and owners as outlined in Jensen and Meckling (1976) and has received substantial attention by investors and academics alike (Byrd et al., 1998; Donaldson, 1963)

While manager have a fiduciary duty to act in the shareholders' best interest, their competing motives, combined with their executive authority and superior knowledge of the firm, lead them to act otherwise. Ceteris paribus, managers prefer a conservative risk profile for their firms for several reasons. John et al. (2008) explain how it is easier for managers to divert cash flows for their own private benefits and perquisite consumption when company earnings are less volatile. By avoiding the possibility of low cash-flow states, managers can continue misappropriating funds while avoiding detection. This problem can be quite serious, as "the opportunity for managers to abscond with financier's funds, or to squander them on pet projects, are plentiful and well-documented" (Shleifer and Vishny, 1997). Another main reason is managers' lack of diversification. Because typical compensation consists of a large portion of equity, managers are commonly exposed to a relatively high degree of firm-specific risk. This exposure induces them to be more risk-averse in order to protect their own wealth. 
Corporate risk-taking has been examined from many different angles. Stronger creditor rights have been linked to reduced risk-taking (Acharya, Amihud, and Litov, 2011; King and Wen, 2011), indicating that managers will do more to avoid the risk of bankruptcy when creditors are powerful. Similarly, strong influence from non-shareholder stakeholders such as banks, employee labor unions, and governments may also seek to curb managerial risk-taking as they generally prioritize stability and continued employment over maximizing profits (John et al., 2008).

Regarding personal characteristics, managers with greater propensity for personal risk-taking, as indicated by having a private pilot license for example, are associated with riskier firms that have abnormally high equity return volatility (Cain and McKeon, 2016). Firms with female managers have been found to be less risky with lower leverage, less earnings volatility, and a higher probability of survival (Faccio, Marchica, and Mura, 2016). This leads us to the first research hypothesis. More recently, board gender diversity has positive impacts on managerial risk-taking (Charjuthamard, et al.; 2021, Mohsni, et al.; 2021).

H1: Managerial risk-taking is positively related to firm value.

However, there appear to be cases, where the degree of managerial risk-taking is excessive. One study examines the role of severance pay in cases where managers take extreme risks out of desperation, such as taking on negative NPV projects, in an attempt to meet predetermined performance targets (Van Wesep and Wang, 2014). In a related study, Dong, Wang, and Xie (2010) investigate whether ESO (Executive Stock Option) induces excessive risk-taking. They find that higher vega values raises the possibility that the manager chooses debt over equity as a capital-raising vehicle, even in cases where the firm is already over-levered. This suggests that the original incentive-aligning effects of stock options may no longer hold, and that the manager is prioritizing own private benefits via option payoffs over the interests of shareholders. Both cases suggest that increased risk-taking is beneficial only up to a certain point, beyond which it becomes detrimental to shareholders.

This situation is analogous to the relationship between managerial ownership and firm value, as outlined by Morck, Shleifer, and Vishny (1988). When the manager has equity ownership in the firm that he manages, they find a non-monotonic relation between ownership and Tobin's Q. They argue that at lower levels of ownership, firm value should increase with ownership as a result of the incentive-alignment effect. Since managers' wealth becomes more tied to their firms, he is more incentivized to perform and drive up the share price. However, at higher levels of ownership, firm value should decrease with ownership as a result of entrenchment effects. Owning a large stake in the firm comes with high firm-specific risk that may allow the manager to remain overly risk-averse without fear of removal. Similarly, prior evidence suggests that managerial risk-taking may also have a non-monotonic relation with firm value. This leads us to the second research hypothesis:

$\mathrm{H} 2$ : At higher levels of managerial risk-taking, risk-taking is negatively related to firm value.

On the other hand, the shareholders, due to their generally diversified position, prefer that managers be willing to accept more risk in order to undertake more profitable projects. To this end, shareholders and boards can implement certain corporate governance bylaws or compensation packages that encourage more risk-taking. John et al. (2008) find that stronger corporate governance induces managers to act more in line with shareholder interests via greater risk-taking. By curbing the managers' ability to act in their own interest, strong corporate governance can induce the manager to adopt a risk profile more closely aligned to shareholder preferences and make decisions that maximize firm value. More recently, Ongsakul and Jiraporn (2019) show that effective governance reduces excessive risk-taking induced by powerful risk-taking incentives. Because corporate governance quality has been determined to positively affect both firm value (Gompers et al., 2003; Cremers and Ferrell, 2014) and risk-taking (John et al., 2008), we include a proxy for governance quality in this study. Furthermore, when managers are shielded with more protective provisions among a governance index (G-index), they might be incentivized to take on "excessive risk" and increase firm value. In this context, the interaction effect between risk-taking and protective provisions is expected to be positively associated with firm value. Hence,

H3: Corporate governance positively affects firm value.

Wurgler (2000) explains that a fundamental purpose of the economy is to allocate capital efficiently. He proposes that in developed economies, capital should flow into promising and growing sectors while being withdrawn from unprofitable ones. He finds that countries with more sophisticated financial markets display better allocation of capital in this way. They increase investment in growing industries while decreasing investment in declining industries. Faccio et al. (2016) follow this insight. Obtaining data from Amadeus to construct the necessary variables, they use value-added growth as a proxy for the quality of investments and test the sensitivity of firm investments to value-added growth. If risk-taking is expressed mainly through the manager's selection of investment projects, it 
may be interesting to explore what aspects of their investment decisions contribute to firm value. To this end, we conduct follow-up tests to investigate whether the level of managerial risk-taking affects the efficiency of capital allocation. If managerial risk-taking increases firm value, we expect that the increase is related to the efficiency of capital allocation. We examine whether risk-taking improves the sensitivity of investment to growth opportunities as measured by capital allocation. Thus,

H4: Managerial risk-taking increases the efficiency of capital allocation.

If risk-taking is expressed mainly through the manager's selection of investment projects, it may be interesting to explore what aspects of their investment decisions contribute to firm value. To this end, we conduct follow-up tests to investigate whether the level of managerial risk-taking affects the efficiency of capital allocation.

\section{Data and Methodology}

We describe the sample selection process, explain the construction of key variables, and present descriptive statistics.

\subsection{Data}

Compustat is the primary source of data used in this paper. We gather all available data on US public firms excluding those in the financial or utilities industries (SIC code 6000-6999 and 4900-4999, respectively), as they operate under unique regulations and have different financial reporting characteristics. Since Compustat provides data starting in 1961, our sample year begins in 1961. Each firm must have at least 5 years of available data in order to compute the risk-taking proxy, as explained later in detail. After cleaning the data for missing values, we obtain a main sample of 177,998 firm-year observations across 15,025 firms from 1961 to 2015. The extensive sample period covers various economic booms and busts as well as several regulatory changes.

For robustness, a secondary sample is created to account for the impact of corporate governance quality with data from Institutional Shareholder Services (ISS, formerly RiskMetrics or IRRC). The samples are maintained separately due to the limited nature of the corporate governance data, which results in a drastic decrease in sample size. The secondary sample including corporate governance consists of 26,431 firm-year observations across 2,648 firms from 1990 to 2015.

\subsection{Methodology}

In order to test hypothesis 1 . we estimate the following model as Eq.(1) with OLS regression analysis.

$$
\begin{aligned}
Q_{i, t}= & \beta_{0}+\beta_{1} \text { RISK }_{i, t}+\beta_{2} \ln \left(\text { Assets }_{i, t}+\beta_{3} \text { Leverage }_{i, t}+\beta_{4} \text { Sales growth }_{i, t}\right. \\
& +\beta_{5} \text { CAPEX }_{i, t}+\beta_{6} \text { PPE }_{i, t}+\beta_{7} \text { SPdummy } \varepsilon_{i, t}
\end{aligned}
$$

where $\mathrm{Q}$ is used as the proxy for firm value, Tobin's Q. Under the assumption that financial markets are efficient, a firm's market value should represent an unbiased estimate of the present value of its future cash flows. Thus, we measure firm value by Tobin's $\mathrm{Q}$, which is the ratio of the market value to the replacement value of its assets to capture any expected valuation adjustments related to the managers' leadership style and the riskiness of their operations. Consistent with Gompers, Ishii, \& Metrick (2003) and Giroud \& Mueller (2011), Tobin's Q is measured as the market value of assets divided by the book value of assets (Compustat item \#6). The market value of assets is measured as the book value of assets plus the market value of common stock (item $24+$ item 25) minus the book value of common stock (item \#60) minus balance sheet deferred taxes (item \#74). This variable is winsorized at the $1 \%$ level at both tails.

Risk represents the index of risk-taking. Riskier corporate operations have more volatile returns to capital. Thus, we follow prior studies (John et al., 2008; Faccio et al., 2011; Boubakri, Cosset, and Saffar, 2013) and use the volatility of firm-level earnings as the primary measure of managerial risk-taking. RISK1 is computed as the standard deviation of the firm's EBITDA/assets ratio over five-year overlapping periods (current year and past four years). Specifically, RISK is computed as follows:

$$
\begin{aligned}
R I S K_{i, t} & =\sqrt{\frac{1}{T-1} \sum_{t=1}^{T}\left(E_{i, t}-\frac{1}{T} \sum_{t=1}^{T} E_{i, t}\right)^{2}} \\
T & =5 \text { and } E_{i, t}=\frac{E B I T D A_{i, t}}{A_{i, t}}
\end{aligned}
$$


Eq.(2) denotes that the risk-taking measure, RISK, is the standard deviation of the earnings ratio over 5 years. Specifically, for year ' $t$ ', this measure takes the standard deviation over the years ' $t-4$ ' to ' $t$ '. Finally, the standard deviation is multiplied by 100 for scaling purposes. Eq.(3) denotes the earnings before interest, taxes, depreciation, and amortization $\left(E B I T D A_{i . t}\right)$ scaled by total assets $\left(A_{i, t}\right)$ for firm ' $\mathrm{i}$ ' at year ' $\mathrm{t}$ '. This earnings ratio, $E_{i, t}$, is winsorized at the $1 \%$ level at both tails.

$\ln$ (Assets), Leverage, Sales growth, CAPEX, PPE, and SPdummy are control variables known to affect firm value. firm size, leverage, sales growth, capital expenditures, asset tangibility (property, plant, and equipment), and S\&P 500 inclusion, respectively. Firm size is measured as the natural log of the total book value of assets. Leverage is measured as long-term debt scaled by total book value of assets. Sales growth is measured as the current year's total sales scaled by the previous year's. Capital expenditure is measured as capital expenditure minus the sale of PPE, with this difference scaled by total assets. Asset tangibility is measured as the total property, plant, and equipment scaled by total assets. SPDummy is a dummy variable that takes on the value of 1 if the firm is included in the S\&P 500 in the corresponding year, and zero otherwise. All of the above control variables (excluding the S\&P 500 dummy) are winsorized at the $1 \%$ level at both tails.

The coefficient of interest is $\beta_{1}$ in the regression analysis using Eq.(1). If greater risk-taking leads to more value-maximizing decisions and the undertaking of more profitable projects, then $\beta_{1}$ should be positive. On the other hand, if risk-taking becomes excessive and value-destroying, then $\beta_{1}$ should be insignificant or even negative.

We estimate the Eq.(1) for subsamples classified by the size of risk-taking to test hypothesis 2 . We compare and analyze the OLS regression results of subsamples either by dividing our sample into two subsamples by the median value of risk-taking or three subsamples based on the size of risk-taking. We also take into account firm fixed effects or industry fixed effects and examine the results from the analysis for subsamples by several different periods.

On the other hand, regressing firm value on managerial risk-taking leaves open the possibility of endogeneity issues. First, there are likely omitted variables that affect both the dependent and independent variables. Omitted variables can include factors such as firm culture, the personality characteristics of the managers, or other outside forces that could confound any attempt to measure the risk-firm value relationship directly. For example, Imhof and Seavey (2014) study the effect of high earnings forecasts by managers on risk-taking and firm value and report that firms with forecasts of high earnings have reduced managerial risk-taking. They also find evidence that when managerial earnings forecasts are high, the positive relation between risk-taking and firm value becomes weaker. Second, the model could suffer from simultaneity bias, in which the direction of causality runs both ways. While risk-taking tendencies can affect firm value through the selection of corporate investment projects, firm value can also affect risk-taking. For instance, a poorly performing firm might lead the manager to take more risks in a desperate attempt to meet certain performance targets. Another possibility is that companies with certain firm values may tend to hire managers with particular risk tendencies. In either case, endogeneity caused by omitted variables or simultaneity bias can result in biased and inconsistent estimates. We address this issue with 2SLS (2 stage least square) estimation.

Chan and Ma (2011) employ a three stage least square approach to address ESO, risk-taking, as well as firm performance and find that while ESO increases risk-taking, managers' risk-aversion constrains risk-taking. In the instrumental variables approach employed in this paper, we use the same instrument for risk-taking as is used in John et al. (2008): the average risk-taking value in the corresponding industry-year. We use only one instrument given the general difficulty in finding one that is suitable, and thus our model is exactly identified. The Durbin-Wu-Hausman test should confirm whether or not the risk-taking variable is endogenous.

We employ the model as Eq.(4) to test to test hypothesis 3 which is related how the interaction effect between risk-taking and protective provisions is associated with firm value.

$$
\begin{aligned}
Q_{i, t} & =\beta_{0}+\beta_{1} \text { RISK }_{i, t}+\beta_{2} \text { Inv.E-Index }_{i, t}+\beta_{3} \ln \left(\text { Assets }_{i, t}+\beta_{4} \text { Leverage }_{i, t}\right. \\
& +\beta_{5} \text { Sales growth }_{i, t}+\beta_{6} \text { CAPEX }_{i, t}+\beta_{7} \text { PPE }_{i, t}+\beta_{8} \text { SPdummy } \varepsilon_{i, t}
\end{aligned}
$$

In Eq.(4) Inv.E-Index represents the degree of shareholder rights (i.e. corporate governance quality). We obtain data from ISS (formerly RiskMetrics or IRRC) in order to construct the Entrenchment-Index (hereafter E-Index) following Bebchuk, Cohen, and Ferrell (2009). This database is the source of the well-known G-Index developed by Gomper et al. (2003) and continues to be used in a large number of academic studies on corporate governance. In this study, we employ the E-Index, which consists of the six corporate governance provisions within the G-Index that are largely responsible for the findings in Gompers et al. (2003). For each firm-year, the E-index measures the presence of six corporate governance provisions that undermine shareholder rights. Specifically, the six provisions 
include (1) staggered boards, (2) limits to shareholder bylaw amendments, (3) golden parachutes, (4) poison pills, (5) supermajority requirements for mergers, and (6) supermajority requirements for charter amendments. For each firm-year, the E-Index takes on a value equivalent to the total number of provisions currently in effect, ranging from 0 to 6 . For ease of interpretation, we use the inverted E-index in this study by taking 6 minus the original E-Index score. In this way, the E-Index increases with shareholder rights (i.e. corporate governance quality). (Note 1)

In line with the risk incentive theory of hedging strategy proposed by Croci et al. (2017), we examine impacts of protective provisions available to corporate executives via risk-taking on firm value using the model as Eq.(5).

$$
\begin{aligned}
Q_{i, t} & =\beta_{0}+\beta_{1} \mathrm{RISK}^{*} \text { Protect }_{i, t}+\beta_{2} \mathrm{RISK}_{i, t}+\beta_{3} \text { Protect }_{i, t}+\beta_{4} \ln \left(\text { Assets }_{i, t}\right. \\
& +\beta_{5} \text { Leverage }_{i, t}+\beta_{6} \text { Sales growth }_{i, t}+\beta_{7} \text { CAPEX }_{i, t}+\beta_{8} \text { PPE }_{i, t}+\beta_{9} \text { SPdummy }+\varepsilon_{i, t}
\end{aligned}
$$

where Protect is a dummy variable that equals 1 if a firm-year has the specified protective provision in place, including CompPlan (compensation plans with change in control), Indem (Indemnification contracts), DirLiab (Director Liability), Severance (Severance agreements), GParachute (Golden parachutes), and P-Index (the sum of all protective provision variables). When managers are protected, they might be incentivized to take more risk and increase firm value. Hence, we expect the interaction effect between the P-index and risk-taking to be positive.

We use the following models as Eq.(6) and Eq.(7) to test hypothesis 4. The models include interaction variables to test whether risk-taking affects the sensitivity of investment to growth opportunities.

$$
\begin{aligned}
& \% \Delta \mathrm{PPE}_{i, t}=\alpha_{0}+\alpha_{1} \mathrm{GVA}_{i, t}+\alpha_{2} \mathrm{GVA}_{i, t} \times{\mathrm{RISK} . U p p e r . M \mathrm{Ud}_{i, t}} \\
& +\alpha_{3} \text { Emp }_{i, t}+\alpha_{4} \frac{\text { Cash Flow }_{i, t}}{T F A_{i, t-1}}+\alpha_{5} \text { Depr.Miss }_{i, t}+\alpha_{6} \ln (1+\text { Age })_{i, t}+u_{i, t} \\
& \% \Delta \mathrm{PPE}_{i, t}=\beta_{0}+\beta_{1} \mathrm{GVA}+\beta_{2} \mathrm{GVA}_{i, t} \times \text { RISK.Mid.Third }_{i, t}+\beta_{3} \mathrm{GVA}_{i, t} \times \text { RISK.Top.Third }_{i, t} \\
& +\beta_{4} \operatorname{Emp}_{i, t}+\beta_{5} \frac{\text { Cash Flow }_{i, t}}{T F A_{i, t-1}}+\beta_{6} \text { Depr.Miss }+\beta_{7} \ln (1+\text { Age })_{i, t}+\eta_{i, t}
\end{aligned}
$$

where the first term, " $\% \Delta \mathrm{PPE}_{\mathrm{i}, \mathrm{t}}$ ", in Eq.(6) is a dependent variable as investment, defined as the percent change in total fixed assets. It is measured as the annual change in PPE scaled by lagged PPE for firm i in year t. GVA is the growth in value-added, which Faccio et al. (2016) measure as the difference between the natural log of value added in year $\mathrm{t}$ and the natural $\log$ of value added in year $\mathrm{t}-1$. In their study, they define value added as earnings before interest and taxes (EBIT) plus the cost of employees. However, as we do not have access to Amadeus, we cannot obtain the same data on the cost of employees. At the same time, Compustat data on wages, salaries, and staff costs are virtually all missing values. In order to work around the data limitation, we define GVA as $\ln \left(1+\mathrm{EBIT}_{t} / \mathrm{EBIT}_{t-1}\right)$. We then include the number of employees (Emp) in the model as a rough proxy of employee costs. RISKUpperMed is a dumm variable that takes the value of 1 if the firm has an average risk-taking value above the sample median, and zero otherwise. CF/TFA is net income plus depreciation divided by total fixed assets.

Similarly, in Eq.(7), RISKMidThird (RISKTopThird) is a dummy variable that takes the value of one if the firm has an average risk-taking value in the middle (top) third of the sample and zero otherwise. Cash Flow is net income plus depreciation. Compustat data on depreciation is very limited. Thus, if it is missing, it is set to zero. Meanwhile, another dummy variable, Depr.Miss, takes the value of one if depreciation data is missing, and zero otherwise. $\mathrm{Ln}(1+\mathrm{Age})$ is the natural log of one plus the number of years since its first listing on CRSP.

The coefficients of interest are those associated with the interaction terms $\left(\alpha_{2}\right.$ in Eq.(6), and $\beta_{2}$ and $\beta_{3}$ in Eq.(7)). In earlier tests, we examine whether managers that take on more risk are associated with firms of higher value. Recall that managerial risk-taking is typically expressed through the manager's selection of corporate investment projects. If risk-taking managers are simply more talented in their selection of risky projects, we would expect them to be more 
efficient in their investments. That is, there would be greater sensitivity in their investments to the growth in value added and we would thus observe positive coefficients for the interaction terms.

On the other hand, if productive risk-taking involves investments focused more on long-term direction and less on immediate payoffs, then investments would be less sensitive to growth in value added, at least in a contemporaneous context. In this case, we would observe a negative coefficient for the interaction terms. Studies that interpret R\&D expenditures as a proxy for risk-taking (Coles et al., 2006; Low, 2009) would fall in line with this view since such expenditures have uncertain returns in the relatively distant future. This would suggest that while risk-taking does not translate directly to immediate growth in value added, the manager's corporate investment decisions are viewed by the market as having favorable prospects and cash flows, resulting in greater firm value.

The above models may raise concerns for reverse causality, in which investment could perhaps contemporaneously impact growth in value added. However, Wurgler (2000) explains that there is an average gap of two years between the investment decision and the moment that fixed capital becomes productive. This would preclude possibilities of reverse causality.

\section{Results}

We present empirical results that show the relation between firm value and risk-taking.

\subsection{Descriptive Statistics}

Panel A of Table 1 reports descriptive statistics of the main variables used in this study. Firms in our sample have an average Tobin's Q of 2.07 and an average earnings volatility (RISK) of 10.62. Both Q and RISK are positively skewed, with the majority of the observations closer to zero. The averages for leverage, sales growth, CAPEX, and PPE is $18 \%, 1.16,7 \%$, and $31 \%$, respectively. 1,079 firms have been included in the S\&P 500 index, which accounts for 17,409 firm-year observations in the main sample.

Table 1. Descriptive statistics

\begin{tabular}{lcccccccc}
\hline Panel A & & & & & & & \\
& $\mathrm{n}$ & Mean & S.D. & Min & $\mathrm{q} 25$ & Mdn & $\mathrm{q} 75$ & Max \\
\hline Tobin's Q & 177,998 & 2.07 & 3.65 & 0.48 & 0.96 & 1.27 & 1.93 & 46.21 \\
RISK & 177,998 & 10.62 & 23.95 & 0 & 2.39 & 4.46 & 8.94 & 290.32 \\
ln(Assets) & 177,998 & 4.82 & 2.33 & -1.82 & 3.2 & 4.69 & 6.36 & 10.89 \\
Leverage & 177,998 & 0.18 & 0.2 & 0 & 0.01 & 0.14 & 0.28 & 1.08 \\
Sales growth & 177,998 & 1.16 & 0.62 & 0.07 & 0.97 & 1.08 & 1.21 & 6.67 \\
CAPEX & 177,998 & 0.07 & 0.08 & -0.01 & 0.02 & 0.05 & 0.09 & 0.51 \\
PPE & 177,998 & 0.31 & 0.23 & 0 & 0.12 & 0.26 & 0.45 & 0.94 \\
SP dummy & 177,998 & 0.1 & 0.3 & 0 & 0 & 0 & 0 & 1 \\
Inv. E-Index & 26,431 & 3.38 & 1.52 & 0 & 2 & 3 & 5 & 6 \\
\hline Panel B & & & & & & & & \\
& 139,572 & 0.05 & 0.44 & -3.45 & -0.03 & 0.1 & 0.23 & 0.95 \\
\hline \% $\triangle$ PPE & 139,572 & 0.63 & 0.49 & 0 & 0.23 & 0.71 & 0.86 & 8.12 \\
GVA & 139,572 & -0.52 & 6.83 & -91.07 & 0.08 & 0.26 & 0.55 & 12.13 \\
CF/TFA & 139,572 & 9.63 & 35.67 & 0 & 0.28 & 1.28 & 5.4 & 2200 \\
Employees & 139,572 & 2.44 & 0.84 & 0 & 1.79 & 2.4 & 3 & 4.5 \\
ln(1+Age) & Mean & S.D. & Min & $\mathrm{q} 25$ & Mdn & $\mathrm{q} 75$ & Max \\
\hline
\end{tabular}

This table reports the descriptive statistics for the main variables used in this paper. The main sample consists of 177,998 firm-year observations across 15,025 firms from 1961 to 2015. Tobin's $Q$ is defined as the market value of assets divided by the book value of assets, where the market value of assets equals the book value of assets plus the market value of common stock minus the book value of common stock minus deferred taxes. RISK is the volatility of firm earnings, measured as 100 times the standard deviation of the firm's EBITDA to assets ratio over 5-year overlapping periods. $\ln$ (Assets) is the natural log of total assets in $\$$ millions. Leverage is defined as long-term debt scaled by total assets. Sales growth is defined as the current year's total sales scaled by the previous year's. CAPEX is 
defined as capital expenditures minus the sales of property, plant, and equipment, with this difference scaled by total assets. PPE is defined as net property, plant, and equipment scaled by total assets. SP dummy is a dummy variable that takes on the value of 1 if the firm is included in the S\&P 500 index in the corresponding year, and zero otherwise. The Inv. (inverted) E-Index is measured as 6 minus the number of specified governance provisions in effect for a given firm-year. \% $\triangle P P E$ is the annual change in PPE scaled by lagged PPE. GVA is growth in value added, defined as $\ln (1+$ EBIT divided by lagged EBIT) . CF/TFA is net income plus depreciation, all scaled by total fixed assets. Employees is the number of employees in thousands. $\ln (1+A g e)$ is the natural $\log$ of 1 plus the number of years since its first listing on CRSP.

Table 2 reports pairwise correlations between the same variables. Consistent with prior studies (Jiao, 2010; Bebchuk and Cohen, 2005), we find that Tobin's Q is positively correlated with sales growth and capital expenditures and is negatively correlated with assets and leverage. More importantly, the table reports a relatively strong positive correlation between risk-taking and firm value, with a coefficient of 0.54 that is statistically significant. In the following section, we conduct more empirical tests to determine whether the positive association holds while controlling for outside variables and endogeneity. Panel B of Tables 1 and 2 provides the same report for variables used in follow-up tests, which are explained in detail in subsection 4.4.

Table 2. Sample correlations

\begin{tabular}{|c|c|c|c|c|c|c|c|c|c|}
\hline \multicolumn{10}{|l|}{ Panel A } \\
\hline & $\begin{array}{c}\text { Tobin's } \\
\text { Q }\end{array}$ & RISK & $\begin{array}{c}\text { Ln } \\
\text { (Assets) }\end{array}$ & Leve-rage & $\begin{array}{l}\text { Sales } \\
\text { growth }\end{array}$ & CAPEX & PPE & $\begin{array}{c}\text { SP } \\
\text { dummy }\end{array}$ & Inv.E-Index \\
\hline Tobin's Q & 1 & & & & & & & & \\
\hline RISK & $0.544^{*}$ & 1 & & & & & & & \\
\hline $\ln$ (Assets) & $-0.272 *$ & $-0.388^{*}$ & 1 & & & & & & \\
\hline Leverage & $-0.006^{*}$ & $-0.029 *$ & $0.164 *$ & 1 & & & & & \\
\hline $\begin{array}{l}\text { Sales } \\
\text { growth }\end{array}$ & $0.062 *$ & $0.117^{*}$ & $-0.021^{*}$ & 0.004 & 1 & & & & \\
\hline CAPEX & $0.011 *$ & -0.001 & $0.042 *$ & $0.104^{*}$ & $0.071^{*}$ & 1 & & & \\
\hline PPE & $-0.123 *$ & $-0.140^{*}$ & $0.201^{*}$ & $0.272 *$ & -0.004 & $0.523 *$ & 1 & & \\
\hline SP dummy & $-0.031 *$ & $-0.104 *$ & $0.409 *$ & $0.015^{*}$ & $-0.033^{*}$ & $0.010 *$ & $0.080 *$ & 1 & \\
\hline $\begin{array}{l}\text { Inv. } \\
\text { E-Index }\end{array}$ & $0.062 *$ & $0.084 *$ & $-0.153^{*}$ & $-0.013^{*}$ & $0.035^{*}$ & $0.057 *$ & $0.014 *$ & $-0.063^{*}$ & 1 \\
\hline \multicolumn{10}{|l|}{ Panel B } \\
\hline & $\% \triangle \mathrm{PPE}$ & GVA & CF/TFA & Emplo-yees & $\ln (1+$ Age $)$ & & & & \\
\hline$\% \triangle \mathrm{PPE}$ & 1 & & & & & & & & \\
\hline GVA & $0.202 *$ & 1 & & & & & & & \\
\hline $\mathrm{CF} / \mathrm{TFA}$ & $0.303 *$ & $0.231 *$ & 1 & & & & & & \\
\hline Employees & $0.026^{*}$ & $0.059 *$ & $0.036^{*}$ & 1 & & & & & \\
\hline $\ln (1+$ Age $)$ & $-0.023 *$ & $0.058 *$ & $0.049 *$ & $0.201 *$ & 1 & & & & \\
\hline
\end{tabular}

This table reports correlation coefficients between the main variables used in this paper. The main sample consists of 177,998 firm-year observations across 15,025 firms from 1961 to 2015. Tobin's $Q$ is defined as the market value of assets divided by the book value of assets, where the market value of assets equals the book value of assets plus the market value of common stock minus the book value of common stock minus deferred taxes. RISK is the volatility of firm earnings, measured as 100 times the standard deviation of the firm's EBITDA to assets ratio over 5-year overlapping periods. $\ln$ (Assets) is the natural log of total assets in $\$$ millions. Leverage is defined as long-term debt scaled by total assets. Sales growth is defined as the current year's total sales scaled by the previous year's. CAPEX is defined as capital expenditures minus the sales of property, plant, and equipment, with this difference scaled by total 
assets. PPE is defined as net property, plant, and equipment scaled by total assets. SP dummy is a dummy variable that takes on the value of 1 if the firm is included in the S\&P 500 index in the corresponding year, and zero otherwise. The Inv. (inverted) E-Index is measured as 6 minus the number of specified governance provisions in effect for a given firm-year. \% $\triangle P P E$ is the annual change in PPE scaled by lagged PPE. GVA is growth in value added, defined as $\ln (1+$ EBIT divided by lagged EBIT $)$. CF/TFA is net income plus depreciation, all scaled by total fixed assets. Employees is the number of employees in thousands. $\ln (1+A g e)$ is the natural $\log$ of 1 plus the number of years since its first listing on CRSP. * represents significance at the 5\% level.

\subsection{Ordinary Least Squares}

Table 3 reports OLS regression results where each column represents a different subsample. While both Model 1 and 5 use the full sample, Model 1 focuses on the volatility of earnings with RISK alone. Model 3 and 5 bring attention to firms with above-median risk-taking. Model 2 (Model 3) uses a subsample of firms that have an average risk-taking value below (above) the sample median. Models $4-5$ use subsamples of firms that have an average risk-taking value in the bottom third and top third of the sample, respectively. By using subsamples based on risk-taking, we analyze whether the relation between risk-taking and firm value depends on the current level of risk-taking. Firm and year fixed effects are included while standard errors are clustered by both firm and year.

The full sample regression in Model 1 of Table 3 reports that risk-taking has an overall positive effect on firm value, with a coefficient of 0.042 that is significant at the $1 \%$ level. To evaluate economic significance of this association, we apply the coefficient to a median firm. If a firm with the median Tobin's Q at 1.27 as in Table 1 increases its risk-taking by one standard deviation at 23.95 from its median risk-taking at 4.46 as in Table 1, its firm value measured as Tobin's Q increases by $1.0059(=0.042 \times 23.95)$. Hence, the Tobin's Q jumps by $79 \%(=1.0059 / 1.27)$ from 1.27 to 2.2759 .

The lower-median subsample (Model 2), which consists of firms with relatively low levels of risk-taking, shows that risk-taking has no effect on firm value. However, the upper-median subsample (Model 3) indicates a positive relation at 0.043 between the two variables. A similar trend is observed in Models $4-5$, in which the subsample with the lowest risk-taking has no effect on firm value (Model 4) but subsamples with more risk-taking does show a positive relation (Models 5). Incorporating the results in Model 1, 3, and 5, we find that the overall impact of risk-taking on firm value is positive. Our findings support Hypothesis 1 as risk-taking is positively related to firm value but do not support Hypothesis 2 as risk-taking still positively affects firm value at higher levels of risk-taking.

Table 3. Managerial risk-taking to firm value with firm fixed effects

\begin{tabular}{|c|c|c|c|c|c|}
\hline & (1) & (2) & (3) & (4) & (5) \\
\hline $\begin{array}{l}\text { Dependent var: } \\
\text { Tobin's Q }\end{array}$ & $\begin{array}{c}\text { Full } \\
\text { Sample }\end{array}$ & Lower Median & $\begin{array}{l}\text { Upper } \\
\text { Median }\end{array}$ & $\begin{array}{l}\text { Bottom } \\
\text { Third }\end{array}$ & $\begin{array}{l}\text { Top } \\
\text { Third }\end{array}$ \\
\hline RISK & $\begin{array}{c}0.0422 * * * \\
(14.11)\end{array}$ & $\begin{array}{c}-0.00598 \\
(-0.91)\end{array}$ & $\begin{array}{c}0.0432 * * * \\
(15.78)\end{array}$ & $\begin{array}{l}-0.0186 \\
(-1.56)\end{array}$ & $\begin{array}{c}0.0413^{* * *} \\
(14.65)\end{array}$ \\
\hline $\operatorname{Ln}$ (Assets) & $\begin{array}{c}-0.940 * * * \\
(-10.31)\end{array}$ & $\begin{array}{c}-0.148 * * * \\
(-5.89)\end{array}$ & $\begin{array}{c}-1.412 * * * \\
(-12.23)\end{array}$ & $\begin{array}{c}-0.148 * * * \\
(-4.64)\end{array}$ & $\begin{array}{c}-1.840 * * * \\
(-13.85)\end{array}$ \\
\hline Leverage & $\begin{array}{c}0.685^{* * *} \\
(4.25)\end{array}$ & $\begin{array}{c}-0.416^{* * *} \\
(-5.84)\end{array}$ & $\begin{array}{c}0.960 * * * \\
(4.75)\end{array}$ & $\begin{array}{c}-0.415 * * * \\
(-5.18)\end{array}$ & $\begin{array}{c}1.108 * * * \\
(4.52)\end{array}$ \\
\hline Sales growth & $\begin{array}{c}0.0358 \\
(1.10)\end{array}$ & $\begin{array}{c}0.211 * * * \\
(9.42)\end{array}$ & $\begin{array}{r}0.0329 \\
(0.99)\end{array}$ & $\begin{array}{c}0.207 * * * \\
(8.25)\end{array}$ & $\begin{array}{l}0.0329 \\
(0.91)\end{array}$ \\
\hline CAPEX & $\begin{array}{c}2.562 * * * \\
(10.60)\end{array}$ & $\begin{array}{c}1.744 * * * \\
(14.00)\end{array}$ & $\begin{array}{c}2.769 * * * \\
(9.01)\end{array}$ & $\begin{array}{c}1.696^{* * * *} \\
(11.56)\end{array}$ & $\begin{array}{c}3.016^{* * * *} \\
(7.99)\end{array}$ \\
\hline
\end{tabular}




\begin{tabular}{lccccc} 
PPE & $-0.819^{* * *}$ & $-0.595 * * *$ & $-0.882^{* * *}$ & $-0.451^{* * *}$ & $-0.956^{* *}$ \\
& $(-4.42)$ & $(-6.59)$ & $(-3.12)$ & $(-4.86)$ & $(-2.45)$ \\
S\&P dummy & & & & \\
& $0.731 * * *$ & 0.0102 & $1.519 * * *$ & 0.0316 & $2.380^{* * * *}$ \\
& $(7.22)$ & $(0.23)$ & $(7.67)$ & $(0.64)$ & $(7.25)$ \\
Observations & & & & \\
R-squared & 177,998 & 87,738 & 88,135 & 57,981 & 58,180 \\
Firm FE & 0.596 & 0.742 & 0.580 & 0.822 & 0.575 \\
Year FE & YES & YES & YES & YES & YES \\
\hline
\end{tabular}

This table reports OLS regression results. The dependent variable is Tobin's Q, defined as the market value of assets divided by the book value of assets, where the market value of assets equals the book value of assets plus the market value of common stock minus the book value of common stock minus deferred taxes. RISK is the volatility of firm earnings, measured as 100 times the standard deviation of the firm's EBITDA to assets ratio over 5-year overlapping periods. $\ln$ (Assets) is the natural log of total assets in \$ millions. Leverage is defined as long-term debt scaled by total assets. Sales growth is defined as the current year's total sales scaled by the previous year's. CAPEX is defined as capital expenditures minus the sales of property, plant, and equipment, with this difference scaled by total assets. $P P E$ is defined as net property, plant, and equipment scaled by total assets. SP dummy is a dummy variable that takes on the value of 1 if the firm is included in the S\&P 500 index in the corresponding year, and zero otherwise. T-statistics based on standard errors clustered by both firm and year are reported below the coefficients. *, **, and *** indicate statistical significance levels of $10 \%, 5 \%$, and $1 \%$, respectively.

While Model 1 shows an overall positive relationship, the subsample results suggest that there is some minimal threshold of risk-taking that must be surpassed before it establishes a relation with firm value. Additionally, the non-significant results may also be due to the fact that the risk-taking variable is highly skewed, with a heavy distribution of observations close to zero. Hence, while subsamples are equal in the number of observations, subsamples with lower levels of risk-taking have a drastically smaller range with respect to the risk-taking variable. We find qualitatively the same results when using the natural log of risk-taking.

The signs of several control variables come out as expected. For instance, both firm size as measured by $\ln ($ assets), and asset tangibility (PPE) have a negative effect on firm value. Meanwhile, being listed in the S\&P 500 Index has a positive effect, which can be reasonably explained by the concomitant increase in exposure, attention, and prestige among investors.

Since our sample period is extensive over several decades, it covers various business cycles and regulatory changes such as Sarbanes-Oxley Act in 2002. Hence, we examine wether the findings in Table 3 are confined to specific periods. Reviewing results from the full sample in Table 4A, we confirm the positive relationship between risk-taking and firm value in general. While coefficients during 1961-1980 and 2011-2015 are insignificant, those during 1981-2010 are positive as in Table 3. The periods with positive relations cover various business cycles including Black Monday of 1987, the dot-com bubble in 2000, and the financial crisis in 2008. 
Table 4A. Full sample: Managerial risk-taking to firm value with firm fixed effects

\begin{tabular}{|c|c|c|c|c|c|c|}
\hline Dep var: & (1) & (2) & (3) & (4) & (5) & (6) \\
\hline Tobin's Q & $1961-1970$ & $1971-1980$ & $1981-1990$ & $1991-2000$ & 2001-2010 & 2011-2015 \\
\hline \multirow[t]{2}{*}{ RISK } & -0.0164 & 0.00133 & $0.0412 * * *$ & $0.0476^{* * *}$ & $0.0253 * * *$ & 0.0146 \\
\hline & $(-1.31)$ & $(0.54)$ & (3.88) & (11.53) & (6.49) & $(1.97)$ \\
\hline \multirow[t]{2}{*}{ Ln(Assets) } & $-0.266^{*}$ & $-0.309 * *$ & $-0.520 * * *$ & $-1.083 * * *$ & $-2.265 * * *$ & $-2.739 * * *$ \\
\hline & $(-2.02)$ & $(-2.92)$ & $(-5.68)$ & $(-11.55)$ & $(-10.40)$ & $(-8.95)$ \\
\hline \multirow[t]{2}{*}{ Leverage } & $-0.961 * * *$ & 0.0112 & -0.0612 & 0.103 & $0.652 * *$ & 1.140 \\
\hline & $(-4.27)$ & $(0.06)$ & $(-0.46)$ & $(0.50)$ & $(2.39)$ & $(2.08)$ \\
\hline \multirow[t]{2}{*}{ Sales Growth } & $0.224 * * *$ & $0.0912 *$ & 0.0740 & $0.138 * *$ & 0.00659 & 0.0685 \\
\hline & $(4.71)$ & $(1.85)$ & (1.63) & $(2.85)$ & $(0.15)$ & $(0.81)$ \\
\hline \multirow[t]{2}{*}{ CAPEX } & $1.462 * * *$ & $1.670 * * *$ & $1.707 * * *$ & $1.748 * * *$ & $2.648 * * *$ & -0.0628 \\
\hline & $(5.08)$ & $(4.31)$ & $(5.41)$ & $(4.88)$ & $(4.55)$ & $(-0.05)$ \\
\hline \multirow[t]{2}{*}{ PPE } & $-0.947 * * *$ & $-0.794 * *$ & -0.465 & $-1.415^{* * *}$ & 0.205 & -1.550 \\
\hline & $(-3.43)$ & $(-3.07)$ & $(-1.52)$ & $(-3.37)$ & $(0.37)$ & $(-1.98)$ \\
\hline \multirow[t]{2}{*}{ S\&P dummy } & -0.00214 & $-0.329 * * *$ & $0.330 * * *$ & $0.775 * * *$ & $1.017 * * *$ & $0.942 * *$ \\
\hline & $(-0.02)$ & $(-3.51)$ & $(4.59)$ & $(4.36)$ & (7.16) & $(4.51)$ \\
\hline \multirow[t]{2}{*}{ Constant } & $2.889 * * *$ & $2.961 * * *$ & $3.132 * * *$ & $6.493 * * *$ & $13.18 * * *$ & $18.55 * * *$ \\
\hline & $(5.65)$ & $(6.95)$ & (9.37) & $(14.28)$ & $(11.52)$ & (10.04) \\
\hline Observations & 8501 & 27497 & 33226 & 43402 & 47082 & 15504 \\
\hline adj. R-sq & 0.771 & 0.681 & 0.560 & 0.586 & 0.697 & 0.808 \\
\hline Firm FE & YES & YES & YES & YES & YES & YES \\
\hline Year FE & YES & YES & YES & YES & YES & YES \\
\hline
\end{tabular}

This table reports OLS regression results. The dependent variable is Tobin's Q, defined as the market value of assets divided by the book value of assets, where the market value of assets equals the book value of assets plus the market value of common stock minus the book value of common stock minus deferred taxes. RISK is the volatility of firm earnings, measured as 100 times the standard deviation of the firm's EBITDA to assets ratio over 5-year overlapping periods. $\ln$ (Assets) is the natural log of total assets in $\$$ millions. Leverage is defined as long-term debt scaled by total assets. Sales growth is defined as the current year's total sales scaled by the previous year's. CAPEX is defined as capital expenditures minus the sales of property, plant, and equipment, with this difference scaled by total assets. $P P E$ is defined as net property, plant, and equipment scaled by total assets. SP dummy is a dummy variable that takes on the value of 1 if the firm is included in the S\&P 500 index in the corresponding year, and zero otherwise. T-statistics based on standard errors clustered by both firm and year are reported below the coefficients. *,**, and *** indicate statistical significance levels of $10 \%, 5 \%$, and $1 \%$, respectively.

To investigate whether the findings sustain among firms with differential risk-taking, we separate OLS on the two groups. Presenting Table 4B for the results on firms below median risk-taking, we find that the impacts of risk-taking on firm value are almost insignificant for the entire sample period except for marginal significance during 1981-1990. However, Table 4C for firms with above-median risk-taking shows results similar to those of the full sample as in Table 3. The positive relations become even better with marginal significance during 2011-2015. 
Table 4B. Firms below median risk-taking: Managerial risk-taking to firm value with firm fixed effects

\begin{tabular}{|c|c|c|c|c|c|c|}
\hline Dependent var: & (1) & (2) & (3) & (4) & (5) & (6) \\
\hline Tobin's Q & $1961-1970$ & $1971-1980$ & $1981-1990$ & $1991-2000$ & 2001-2010 & $2011-2015$ \\
\hline \multirow[t]{2}{*}{ RISK } & -0.0513 & 0.0000111 & $-0.0132 *$ & 0.00414 & 0.00752 & -0.00840 \\
\hline & $(-1.66)$ & $(0.00)$ & $(-2.20)$ & $(0.55)$ & (1.35) & $(-0.76)$ \\
\hline \multirow[t]{2}{*}{ Ln(Assets) } & 0.115 & $-0.281 *$ & $-0.136 * * *$ & $-0.141 * *$ & $-0.248 * * *$ & $-0.369 * *$ \\
\hline & (1.09) & $(-2.07)$ & $(-3.71)$ & $(-2.88)$ & $(-5.46)$ & $(-4.40)$ \\
\hline \multirow[t]{2}{*}{ Leverage } & $-0.607 * *$ & -0.138 & -0.121 & $-0.656 * * *$ & $-0.251 *$ & -0.0201 \\
\hline & $(-2.70)$ & $(-0.86)$ & $(-1.24)$ & $(-5.42)$ & $(-2.11)$ & $(-0.17)$ \\
\hline \multirow[t]{2}{*}{ Sales Growth } & 0.0334 & $0.177 * * *$ & $0.108 * * *$ & $0.213 * * *$ & $0.145^{* * *}$ & $0.150^{* *}$ \\
\hline & $(0.51)$ & $(3.93)$ & (4.66) & (6.18) & $(4.54)$ & $(4.35)$ \\
\hline \multirow[t]{2}{*}{ CAPEX } & $1.677 * * *$ & $1.512 * * *$ & $1.031 * * *$ & $1.596 * * *$ & $1.109 * * *$ & 0.265 \\
\hline & $(5.42)$ & $(4.75)$ & (6.60) & (6.99) & $(5.78)$ & $(1.35)$ \\
\hline \multirow[t]{2}{*}{ PPE } & $-0.725^{*}$ & $-1.068 * * *$ & $-0.796 * * *$ & $-0.530 *$ & $-0.456 * *$ & $-0.886^{* *}$ \\
\hline & $(-2.24)$ & $(-4.13)$ & $(-7.54)$ & $(-2.11)$ & $(-2.91)$ & $(-2.84)$ \\
\hline \multirow[t]{2}{*}{ S\&P dummy } & -0.0406 & $-0.319 * *$ & 0.0829 & $0.191 *$ & 0.0801 & 0.163 \\
\hline & $(-0.25)$ & $(-2.63)$ & (1.44) & $(2.02)$ & (1.02) & $(2.11)$ \\
\hline \multirow[t]{2}{*}{ Constant } & $1.433 * *$ & $3.072 * * *$ & $1.960 * * *$ & $2.248^{* * *}$ & $3.224 * * *$ & $4.305 * * *$ \\
\hline & $(3.10)$ & $(4.84)$ & (10.12) & $(9.46)$ & (10.67) & (7.11) \\
\hline Observations & 4062 & 13384 & 16113 & 21093 & 23069 & 7416 \\
\hline adj. R-sq & 0.882 & 0.629 & 0.702 & 0.679 & 0.902 & 0.957 \\
\hline Firm FE & YES & YES & YES & YES & YES & YES \\
\hline Year FE & YES & YES & YES & YES & YES & YES \\
\hline
\end{tabular}

This table reports OLS regression results. The dependent variable is Tobin's Q, defined as the market value of assets divided by the book value of assets, where the market value of assets equals the book value of assets plus the market value of common stock minus the book value of common stock minus deferred taxes. RISK is the volatility of firm earnings, measured as 100 times the standard deviation of the firm's EBITDA to assets ratio over 5-year overlapping periods. $\ln$ (Assets) is the natural log of total assets in $\$$ millions. Leverage is defined as long-term debt scaled by total assets. Sales growth is defined as the current year's total sales scaled by the previous year's. CAPEX is defined as capital expenditures minus the sales of property, plant, and equipment, with this difference scaled by total assets. $P P E$ is defined as net property, plant, and equipment scaled by total assets. SP dummy is a dummy variable that takes on the value of 1 if the firm is included in the S\&P 500 index in the corresponding year, and zero otherwise. T-statistics based on standard errors clustered by both firm and year are reported below the coefficients. *, **, and *** indicate statistical significance levels of $10 \%, 5 \%$, and $1 \%$, respectively. 
Table 4C. Firms above median risk-taking: Managerial risk-taking to firm value with firm fixed effects

\begin{tabular}{|c|c|c|c|c|c|c|}
\hline Dependent var: & (1) & (2) & (3) & (4) & (5) & (6) \\
\hline Tobin's Q & $1961-1970$ & 1971-1980 & $1981-1990$ & $1991-2000$ & 2001-2010 & $2011-2015$ \\
\hline \multirow[t]{2}{*}{ RISK } & -0.0144 & 0.00256 & $0.0439 * * *$ & $0.0474 * * *$ & $0.0285 * * *$ & $0.0158 *$ \\
\hline & $(-0.98)$ & $(0.88)$ & $(3.59)$ & (11.26) & (7.23) & $(2.26)$ \\
\hline \multirow[t]{2}{*}{ Ln(Assets) } & $-0.357 * *$ & $-0.300 * *$ & $-0.747 * * *$ & $-1.545 * * *$ & $-2.917 * * *$ & $-3.367 * * *$ \\
\hline & $(-2.53)$ & $(-2.81)$ & $(-6.19)$ & $(-12.70)$ & $(-12.58)$ & $(-10.47)$ \\
\hline \multirow[t]{2}{*}{ Leverage } & $-1.163^{* * *}$ & 0.150 & -0.161 & 0.163 & 0.588 & 0.885 \\
\hline & $(-3.55)$ & $(0.55)$ & $(-0.86)$ & $(0.55)$ & $(1.57)$ & $(1.23)$ \\
\hline \multirow[t]{2}{*}{ Sales Growth } & $0.232 * * *$ & 0.0471 & 0.0558 & $0.146^{* *}$ & 0.0151 & 0.0366 \\
\hline & $(5.51)$ & $(0.86)$ & $(0.95)$ & $(2.61)$ & $(0.30)$ & $(0.41)$ \\
\hline \multirow[t]{2}{*}{ CAPEX } & $1.380^{* * *}$ & $1.516^{* * *}$ & $1.761 * * *$ & $1.962 * * *$ & $2.749 * * *$ & -0.191 \\
\hline & $(3.92)$ & $(4.05)$ & $(4.31)$ & (3.89) & $(3.77)$ & $(-0.12)$ \\
\hline \multirow[t]{2}{*}{ PPE } & $-1.409 * * *$ & -0.597 & 0.00865 & $-1.838 * *$ & 0.485 & -1.683 \\
\hline & $(-3.53)$ & $(-1.75)$ & $(0.02)$ & $(-2.92)$ & $(0.63)$ & $(-1.61)$ \\
\hline \multirow[t]{2}{*}{ S\&P dummy } & -0.139 & -0.118 & $0.455^{*}$ & $1.102 * *$ & $1.873 * * *$ & $1.441 * *$ \\
\hline & $(-1.29)$ & $(-1.46)$ & $(2.25)$ & $(3.09)$ & $(5.06)$ & $(3.44)$ \\
\hline \multirow[t]{2}{*}{ Constant } & $3.081 * * *$ & $2.672 * * *$ & $3.312 * * *$ & $7.118^{* * *}$ & $13.14 * * *$ & $18.69 * * *$ \\
\hline & $(6.02)$ & $(7.22)$ & $(9.41)$ & (15.33) & (14.16) & (11.70) \\
\hline Observations & 4024 & 13385 & 16082 & 20899 & 22982 & 7363 \\
\hline adj. R-sq & 0.709 & 0.716 & 0.538 & 0.555 & 0.671 & 0.782 \\
\hline Firm FE & YES & YES & YES & YES & YES & YES \\
\hline Year FE & YES & YES & YES & YES & YES & YES \\
\hline
\end{tabular}

This table reports OLS regression results. The dependent variable is Tobin's Q, defined as the market value of assets divided by the book value of assets, where the market value of assets equals the book value of assets plus the market value of common stock minus the book value of common stock minus deferred taxes. RISK is the volatility of firm earnings, measured as 100 times the standard deviation of the firm's EBITDA to assets ratio over 5-year overlapping periods. $\ln$ (Assets) is the natural log of total assets in $\$$ millions. Leverage is defined as long-term debt scaled by total assets. Sales growth is defined as the current year's total sales scaled by the previous year's. CAPEX is defined as capital expenditures minus the sales of property, plant, and equipment, with this difference scaled by total assets. $P P E$ is defined as net property, plant, and equipment scaled by total assets. SP dummy is a dummy variable that takes on the value of 1 if the firm is included in the S\&P 500 index in the corresponding year, and zero otherwise. T-statistics based on standard errors clustered by both firm and year are reported below the coefficients. *,**, and *** indicate statistical significance levels of $10 \%, 5 \%$, and $1 \%$, respectively.

There are concerns on differential risk-taking in different industries. That is, there is a potential bias that firms with high risk-taking industries might dominate the findings when firms with low risk-taking industries show opposite results. One of commonly adopted ways to address the issue is industry adjustment. Computing industry medians for all the variables in the regression each year, we can deduct industry medians from firm-year observations for clean tests of excessive risk-taking. However, Gormley and Matsa (2014) find that the widely used industry adjustment provides inconsistent estimates and can generate spurious implications. They suggest industry fixed effects for 
consistent estimates. Following Gormley and Matsa (2014), we present results with industry fixed effects in Table 5 and show that the findings in Table 3 become stronger with the fixed effects estimator. While both the full sample and the samples with high risk-taking show positive relations between risk-taking and firm value, the samples with low risk-taking illustrate negative relations.

Table 5. Managerial risk-taking to firm value with industry fixed effects

\begin{tabular}{|c|c|c|c|c|c|}
\hline & (1) & (2) & (3) & (4) & (5) \\
\hline $\begin{array}{l}\text { Dependent var: } \\
\text { Tobin's Q }\end{array}$ & $\begin{array}{c}\text { Full } \\
\text { Sample }\end{array}$ & Lower Median & Upper Median & Bottom Third & $\begin{array}{l}\text { Top } \\
\text { Third }\end{array}$ \\
\hline RISK & $\begin{array}{c}0.0694 * * * \\
(23.80)\end{array}$ & $\begin{array}{c}-0.1000 * * * \\
(-3.25)\end{array}$ & $\begin{array}{c}0.0666 * * * \\
(22.23)\end{array}$ & $\begin{array}{c}-0.252 * * * \\
(-3.72)\end{array}$ & $\begin{array}{c}0.0627 * * * \\
(20.55)\end{array}$ \\
\hline Ln(Assets) & $\begin{array}{c}-0.232 * * * \\
(-6.01)\end{array}$ & $\begin{array}{c}-0.0994 * * * \\
(-2.76)\end{array}$ & $\begin{array}{c}-0.457 * * * \\
(-8.76)\end{array}$ & $\begin{array}{c}-0.164 * * * \\
(-3.16)\end{array}$ & $\begin{array}{c}-0.698 * * * \\
(-10.10)\end{array}$ \\
\hline Leverage & $\begin{array}{c}0.794 * * * \\
(3.19)\end{array}$ & $\begin{array}{c}-0.526^{* * * *} \\
(-3.30)\end{array}$ & $\begin{array}{c}1.538 * * * \\
(5.03)\end{array}$ & $\begin{array}{c}-0.529 * * \\
(-2.42)\end{array}$ & $\begin{array}{c}2.028 * * * \\
(5.93)\end{array}$ \\
\hline Sales growth & $\begin{array}{c}0.00279 \\
(0.06)\end{array}$ & $\begin{array}{c}0.442 * * * \\
(5.21)\end{array}$ & $\begin{array}{l}-0.0193 \\
(-0.39)\end{array}$ & $\begin{array}{c}0.566 * * * \\
(3.72)\end{array}$ & $\begin{array}{l}-0.0225 \\
(-0.43)\end{array}$ \\
\hline CAPEX & $\begin{array}{c}2.495 * * * \\
(8.24)\end{array}$ & $\begin{array}{c}2.719 * * * \\
(9.79)\end{array}$ & $\begin{array}{c}2.682 * * * \\
(6.98)\end{array}$ & $\begin{array}{c}2.950 * * * \\
(7.13)\end{array}$ & $\begin{array}{c}2.930 * * * \\
(6.32)\end{array}$ \\
\hline PPE & $\begin{array}{c}-0.736 * * * \\
(-6.36)\end{array}$ & $\begin{array}{c}-0.687 * * * \\
(-7.40)\end{array}$ & $\begin{array}{c}-0.876 * * * \\
(-4.91)\end{array}$ & $\begin{array}{c}-0.666 * * * \\
(-5.39)\end{array}$ & $\begin{array}{c}-1.049 * * * \\
(-4.41)\end{array}$ \\
\hline S\&P dummy & $\begin{array}{c}1.069 * * * \\
(8.22)\end{array}$ & $\begin{array}{c}0.469 * * * \\
(5.45)\end{array}$ & $\begin{array}{c}1.990 * * * \\
(9.24)\end{array}$ & $\begin{array}{c}0.573 * * * \\
(5.16)\end{array}$ & $\begin{array}{c}2.969 * * * \\
(9.64)\end{array}$ \\
\hline Constant & $\begin{array}{c}2.121 * * * \\
(11.40)\end{array}$ & $\begin{array}{c}1.661 * * * \\
(9.18)\end{array}$ & $\begin{array}{c}2.354 * * * \\
(13.04)\end{array}$ & $\begin{array}{c}2.006^{* * *} \\
(6.95)\end{array}$ & $\begin{array}{c}2.466 * * * \\
(9.38)\end{array}$ \\
\hline Observations & 175,053 & 88,014 & 87,039 & 58,678 & 57,820 \\
\hline R-squared & 0.325 & 0.103 & 0.349 & 0.108 & 0.356 \\
\hline Industry FE & YES & YES & YES & YES & YES \\
\hline Year FE & YES & YES & YES & YES & YES \\
\hline
\end{tabular}

This table reports OLS regression results. The dependent variable is Tobin's Q, defined as the market value of assets divided by the book value of assets, where the market value of assets equals the book value of assets plus the market value of common stock minus the book value of common stock minus deferred taxes. RISK is the volatility of firm earnings, measured as 100 times the standard deviation of the firm's EBITDA to assets ratio over 5-year overlapping periods. $\ln$ (Assets) is the natural log of total assets in \$ millions. Leverage is defined as long-term debt scaled by total assets. Sales growth is defined as the current year's total sales scaled by the previous year's. CAPEX is defined as capital expenditures minus the sales of property, plant, and equipment, with this difference scaled by total assets. $P P E$ is defined as net property, plant, and equipment scaled by total assets. SP dummy is a dummy variable that takes on the value of 1 if the firm is included in the S\&P 500 index in the corresponding year, and zero otherwise. T-statistics based on standard errors clustered by both firm and year are reported below the coefficients. *,**, and *** indicate statistical significance levels of $10 \%, 5 \%$, and $1 \%$, respectively. 


\subsection{Endogeneity: Two-Stage Least Squares}

To supplement the findings of the preceding subsection with concerns on potential endogeneity, we conduct the 2SLS regression analysis using an instrumental variables approach. The results are reported in Table 6 . Similar to the preceding subsection, we regress Tobin's Q on instrumented RISK with the same set of control variables.

Table 6. 2SLS: Managerial risk-taking to firm value with firm fixed effects

\begin{tabular}{|c|c|c|c|c|c|}
\hline $\begin{array}{l}\text { Dependent var: } \\
\text { Tobin's Q }\end{array}$ & $\begin{array}{c}\text { (1) } \\
\text { Full } \\
\text { Sample }\end{array}$ & $\begin{array}{c}\text { (2) } \\
\text { Lower Median }\end{array}$ & $\begin{array}{c}\text { (3) } \\
\text { Upper Median }\end{array}$ & $\begin{array}{c}\text { (4) } \\
\text { Bottom Third }\end{array}$ & $\begin{array}{c}\text { (5) } \\
\text { Top } \\
\text { Third }\end{array}$ \\
\hline $\begin{array}{c}\text { Instrumented } \\
\text { RISK }\end{array}$ & $\begin{array}{c}0.134 * * * \\
(9.17)\end{array}$ & $\begin{array}{c}0.695 * * * \\
(2.59)\end{array}$ & $\begin{array}{c}0.122 * * * \\
(8.99)\end{array}$ & $\begin{array}{l}1.566^{*} \\
(1.94)\end{array}$ & $\begin{array}{c}0.115^{* * * *} \\
(8.36)\end{array}$ \\
\hline Ln(Assets) & $\begin{array}{c}-0.266^{* * *} \\
(-5.18)\end{array}$ & $\begin{array}{l}-0.0126 \\
(-0.36)\end{array}$ & $\begin{array}{c}-0.657 * * * \\
(-6.93)\end{array}$ & $\begin{array}{c}-0.00963 \\
(-0.24)\end{array}$ & $\begin{array}{c}-1.044 * * * \\
(-7.74)\end{array}$ \\
\hline Leverage & $\begin{array}{l}0.131 \\
(0.73)\end{array}$ & $\begin{array}{c}-0.580 * * * \\
(-6.31)\end{array}$ & $\begin{array}{l}0.411 * \\
(1.82)\end{array}$ & $\begin{array}{c}-0.667 * * * \\
(-4.03)\end{array}$ & $\begin{array}{c}0.624 * * \\
(2.26)\end{array}$ \\
\hline Sales growth & $\begin{array}{c}-0.112 * * \\
(-2.28)\end{array}$ & $\begin{array}{c}0.178^{* * * *} \\
(6.55)\end{array}$ & $\begin{array}{c}-0.115^{* *} \\
(-2.32)\end{array}$ & $\begin{array}{c}0.165 * * * \\
(4.81)\end{array}$ & $\begin{array}{c}-0.121 * * \\
(-2.36)\end{array}$ \\
\hline CAPEX & $\begin{array}{c}1.647 * * * \\
(5.96)\end{array}$ & $\begin{array}{c}1.581 * * * \\
(10.28)\end{array}$ & $\begin{array}{c}1.797 * * * \\
(4.76)\end{array}$ & $\begin{array}{c}1.301 * * * \\
(5.60)\end{array}$ & $\begin{array}{c}2.030 * * * \\
(4.40)\end{array}$ \\
\hline PPE & $\begin{array}{c}-0.519 * * \\
(-2.19)\end{array}$ & $\begin{array}{c}-0.631 * * * \\
(-5.05)\end{array}$ & $\begin{array}{l}-0.540 * \\
(-1.68)\end{array}$ & $\begin{array}{c}-0.597 * * * \\
(-3.61)\end{array}$ & $\begin{array}{l}-0.708^{*} \\
(-1.73)\end{array}$ \\
\hline S\&P dummy & $\begin{array}{c}0.301^{* * *} \\
(3.54)\end{array}$ & $\begin{array}{l}-0.0300 \\
(-0.60)\end{array}$ & $\begin{array}{c}0.805^{* * *} \\
(4.26)\end{array}$ & $\begin{array}{l}0.0136 \\
(0.21)\end{array}$ & $\begin{array}{c}1.513 * * * \\
(4.49)\end{array}$ \\
\hline Observations & 177,998 & 87738 & 88135 & 57981 & 58180 \\
\hline $\begin{array}{l}\text { R-squared } \\
\text { Firm FE }\end{array}$ & $\begin{array}{c}-0.208 \\
\text { YES }\end{array}$ & $\begin{array}{c}-0.846 \\
\text { YES }\end{array}$ & $\begin{array}{c}-0.151 \\
\text { YES }\end{array}$ & $\begin{array}{c}-2.250 \\
\text { YES }\end{array}$ & $\begin{array}{c}-0.125 \\
\text { YES }\end{array}$ \\
\hline Year FE & YES & YES & YES & YES & YES \\
\hline
\end{tabular}

This table reports 2SLS regression results. The dependent variable is Tobin's Q, defined as the market value of assets divided by the book value of assets, where the market value of assets equals the book value of assets plus the market value of common stock minus the book value of common stock minus deferred taxes. RISK is the volatility of firm earnings, measured as 100 times the standard deviation of the firm's EBITDA to assets ratio over 5-year overlapping periods. The instrumental variable is the average risk-taking for the corresponding industry-year. $\ln$ (Assets) is the natural log of total assets in \$ millions. Leverage is defined as long-term debt scaled by total assets. Sales growth is defined as the current year's total sales scaled by the previous year's. CAPEX is defined as capital expenditures minus the sales of property, plant, and equipment, with this difference scaled by total assets. PPE is defined as net property, plant, and equipment scaled by total assets. $S P$ dummy is a dummy variable that takes on the value of 1 if the firm is included in the S\&P 500 index in the corresponding year, and zero otherwise. T-statistics based on standard errors clustered by both firm and year are reported below the coefficients. *, **, and *** indicate statistical significance levels of $10 \%, 5 \%$, and $1 \%$, respectively. 
The 2SLS results are qualitatively the same as those of OLS and supports Hypothesis 1. Risk-taking continues to display a positive and significant relation with firm value in the full sample, the upper median subsample, and the top third subsample, even including the lower median subsample. When we also run 2SLS regressions for sub-periods to each decade in the spirit of Tables 4A-C, we find that results follow those of the full sample in general. (Note 2) When we conduct regressions with industry fixed effects in Table 7, we find that the results are qualitatively the same as those in previous findings.

Table 7. 2SLS: Managerial risk-taking to firm value with industry fixed effects

\begin{tabular}{|c|c|c|c|c|c|}
\hline $\begin{array}{l}\text { Dependent var: } \\
\text { Tobin's Q }\end{array}$ & $\begin{array}{c}\text { (1) } \\
\text { Full Sample }\end{array}$ & $\begin{array}{c}(2) \\
\text { Lower Median }\end{array}$ & $\begin{array}{c}\text { (3) } \\
\text { Upper Median }\end{array}$ & $\begin{array}{c}\text { (4) } \\
\text { Bottom Third }\end{array}$ & $\begin{array}{c}\text { (5) } \\
\text { Top Third }\end{array}$ \\
\hline $\begin{array}{c}\text { Instrumented } \\
\text { RISK }\end{array}$ & $\begin{array}{c}0.0301 * * * \\
\quad(2.71)\end{array}$ & $\begin{array}{l}-0.362 \\
(-1.26)\end{array}$ & $\begin{array}{c}0.0369 * * * \\
(2.91)\end{array}$ & $\begin{array}{l}-0.641 \\
(-0.83)\end{array}$ & $\begin{array}{c}0.0323 * * \\
(2.10)\end{array}$ \\
\hline Ln(Assets) & $\begin{array}{c}-0.434 * * * \\
(-5.67)\end{array}$ & $\begin{array}{c}-0.139 * * \\
(-2.31)\end{array}$ & $\begin{array}{c}-0.671 * * * \\
(-6.93)\end{array}$ & $\begin{array}{c}-0.192 * * \\
(-2.34)\end{array}$ & $\begin{array}{c}-0.960 * * * \\
(-7.16)\end{array}$ \\
\hline Leverage & $\begin{array}{c}1.155^{* * * *} \\
(3.93)\end{array}$ & $\begin{array}{c}-0.497 * * * \\
(-3.12)\end{array}$ & $\begin{array}{c}1.921 * * * \\
(5.95)\end{array}$ & $\begin{array}{c}-0.488 * * \\
(-2.11)\end{array}$ & $\begin{array}{c}2.455^{* * * *} \\
(6.90)\end{array}$ \\
\hline Sales growth & $\begin{array}{c}0.149 * * * \\
(2.79)\end{array}$ & $\begin{array}{c}0.459 * * * \\
(5.55)\end{array}$ & $\begin{array}{r}0.0984 \\
(1.52)\end{array}$ & $\begin{array}{c}0.570 * * * \\
(3.89)\end{array}$ & $\begin{array}{l}0.105 \\
(1.34)\end{array}$ \\
\hline CAPEX & $\begin{array}{c}3.208 * * * \\
(8.16)\end{array}$ & $\begin{array}{c}2.931 * * * \\
(7.75)\end{array}$ & $\begin{array}{c}3.329 * * * \\
(7.18)\end{array}$ & $\begin{array}{c}3.184 * * * \\
(4.93)\end{array}$ & $\begin{array}{c}3.672 * * * \\
(6.38)\end{array}$ \\
\hline PPE & $\begin{array}{c}-1.033 * * * \\
(-6.83)\end{array}$ & $\begin{array}{c}-0.753 * * * \\
(-6.91)\end{array}$ & $\begin{array}{c}-1.160 * * * \\
(-5.35)\end{array}$ & $\begin{array}{c}-0.732 * * * \\
(-4.67)\end{array}$ & $\begin{array}{c}-1.367 * * * \\
(-4.61)\end{array}$ \\
\hline S\&P dummy & $\begin{array}{c}1.501 * * * \\
(7.44)\end{array}$ & $\begin{array}{c}0.464 * * * \\
(5.49)\end{array}$ & $\begin{array}{c}2.555^{* * * *} \\
(8.49)\end{array}$ & $\begin{array}{c}0.565^{* * *} \\
(5.21)\end{array}$ & $\begin{array}{c}3.701 * * * \\
(8.66)\end{array}$ \\
\hline Observations & 175,053 & 88,014 & 87,039 & 58,678 & 57,820 \\
\hline R-squared & 0.276 & 0.071 & 0.321 & 0.082 & 0.329 \\
\hline Industry FE & YES & YES & YES & YES & YES \\
\hline Year FE & YES & YES & YES & YES & YES \\
\hline
\end{tabular}

This table reports 2SLS regression results. The dependent variable is Tobin's Q, defined as the market value of assets divided by the book value of assets, where the market value of assets equals the book value of assets plus the market value of common stock minus the book value of common stock minus deferred taxes. RISK is the volatility of firm earnings, measured as 100 times the standard deviation of the firm's EBITDA to assets ratio over 5-year overlapping periods. The instrumental variable is the average risk-taking for the corresponding industry-year. $\ln$ (Assets) is the natural log of total assets in \$ millions. Leverage is defined as long-term debt scaled by total assets. Sales growth is defined as the current year's total sales scaled by the previous year's. CAPEX is defined as capital expenditures minus the sales of property, plant, and equipment, with this difference scaled by total assets. $P P E$ is defined as net property, plant, and equipment scaled by total assets. SP dummy is a dummy variable that takes on the value of 1 if the firm is included in the S\&P 500 index in the corresponding year, and zero otherwise. T-statistics based on standard errors clustered by both firm and year are reported below the coefficients. *, **, and $* * *$ indicate statistical significance levels of $10 \%, 5 \%$, and $1 \%$, respectively. 
Interestingly, there is still no indication that upper levels of risk-taking become detrimental to firm value. At face value, this suggests that it is in shareholders' interest to do whatever possible to drive up managerial risk-taking without regard to avoiding "excessive" levels. This seems to contradict intuition because continuously increasing risk must at some point become detrimental.

One possible explanation is that the sample excludes financial firms and are thus not prone to excessive levels of risk. Excessive and reckless risk-taking by financial institutions has been the focus of wide debate even before the onset of the global financial crisis and continues to be scrutinized by regulators and academics. By excluding all financial firms, it is possible that the sample firms, on average, can benefit from more risk-taking.

A second possible explanation is survivorship bias. The sample selection process requires that firms have at least 5 years of data to be considered as a risk-taking measure. If a substantial portion of excluded firms failed due to excessive risk-taking, the results of this study must be largely re-examined. However, without more information on the reasons for their failure, it is difficult to conclude whether the survivorship bias is a serious issue.

\subsection{Corporate Governance}

Table 8 shows firm value relative to corporate governance quality proxied by the inverted E-index. However, we cannot find a significant impact of corporate governance on firm value as all the coefficients on the inverted E-index are insignificant and coefficients on risk-taking are similar to those in Table 3.

Table 8. Corporate governance on firm value

\begin{tabular}{|c|c|c|c|c|c|}
\hline $\begin{array}{l}\text { Dependent var: } \\
\text { Tobin's Q }\end{array}$ & $\begin{array}{c}\text { (1) } \\
\text { Full } \\
\text { Sample }\end{array}$ & $\begin{array}{c}\text { (2) } \\
\text { Lower Median }\end{array}$ & $\begin{array}{c}\text { (3) } \\
\text { Upper Median }\end{array}$ & $\begin{array}{c}\text { (4) } \\
\text { Bottom Third }\end{array}$ & $\begin{array}{c}\text { (5) } \\
\text { Top } \\
\text { Third }\end{array}$ \\
\hline RISK & $\begin{array}{c}0.0297 * * \\
(2.10)\end{array}$ & $\begin{array}{c}-0.00449 \\
(-0.49)\end{array}$ & $\begin{array}{c}0.0364 * * \\
(2.32)\end{array}$ & $\begin{array}{c}-0.0134 \\
(-0.96)\end{array}$ & $\begin{array}{c}0.0372 * * \\
(2.36)\end{array}$ \\
\hline Inv. E-Index & $\begin{array}{l}0.0225 \\
(1.36)\end{array}$ & $\begin{array}{l}0.0141 \\
(0.89)\end{array}$ & $\begin{array}{l}0.0438 \\
(1.24)\end{array}$ & $\begin{array}{c}0.0107 \\
(0.66)\end{array}$ & $\begin{array}{c}0.0511 \\
(0.77)\end{array}$ \\
\hline Ln(Assets) & $\begin{array}{c}-0.405 * * * \\
(-6.42)\end{array}$ & $\begin{array}{c}-0.345^{* * * *} \\
(-7.59)\end{array}$ & $\begin{array}{c}-0.568 * * * \\
(-3.55)\end{array}$ & $\begin{array}{c}-0.373^{* * * *} \\
(-6.38)\end{array}$ & $\begin{array}{c}-0.801 \text { *** } \\
(-2.83)\end{array}$ \\
\hline Leverage & $\begin{array}{c}-0.584 * * * \\
(-4.38)\end{array}$ & $\begin{array}{c}-0.745^{* * *} \\
(-6.09)\end{array}$ & $\begin{array}{l}-0.381 \\
(-1.70)\end{array}$ & $\begin{array}{c}-0.858 * * * \\
(-5.54)\end{array}$ & $\begin{array}{l}-0.282 \\
(-0.85)\end{array}$ \\
\hline Sales growth & $\begin{array}{c}0.328 * * * \\
(3.66)\end{array}$ & $\begin{array}{c}0.561 * * * \\
(8.27)\end{array}$ & $\begin{array}{c}0.200 * * \\
(2.07)\end{array}$ & $\begin{array}{c}0.623 * * * \\
(6.33)\end{array}$ & $\begin{array}{l}0.137 \\
(1.27)\end{array}$ \\
\hline CAPEX & $\begin{array}{c}1.883^{* * *} \\
(2.47)\end{array}$ & $\begin{array}{c}2.447 * * * \\
(6.83)\end{array}$ & $\begin{array}{l}1.077 \\
(0.77)\end{array}$ & $\begin{array}{c}2.417 * * * \\
(3.77)\end{array}$ & $\begin{array}{l}0.398 \\
(0.18)\end{array}$ \\
\hline PPE & $\begin{array}{l}-0.255 \\
(-0.67)\end{array}$ & $\begin{array}{c}-0.518 * * * \\
(-2.85)\end{array}$ & $\begin{array}{l}0.284 \\
(0.24)\end{array}$ & $\begin{array}{c}-0.566 * * \\
(-2.55)\end{array}$ & $\begin{array}{l}1.564 \\
(0.69)\end{array}$ \\
\hline S\&P dummy & $\begin{array}{c}0.220 * * * \\
(3.32)\end{array}$ & $\begin{array}{c}0.143^{* *} \\
(2.35)\end{array}$ & $\begin{array}{l}0.334 \\
(1.59)\end{array}$ & $\begin{array}{l}0.138^{*} \\
(2.01)\end{array}$ & $\begin{array}{l}0.517 \\
(1.00)\end{array}$ \\
\hline Observations & 26,256 & 17,756 & 8,170 & 12,684 & 4,098 \\
\hline R-squared & 0.560 & 0.674 & 0.501 & 0.713 & 0.473 \\
\hline Firm FE & YES & YES & YES & YES & YES \\
\hline Year FE & YES & YES & YES & YES & YES \\
\hline
\end{tabular}


This table reports OLS regression results. The dependent variable is Tobin's Q, defined as the market value of assets divided by the book value of assets, where the market value of assets equals the book value of assets plus the market value of common stock minus the book value of common stock minus deferred taxes. RISK is the volatility of firm earnings, measured as 100 times the standard deviation of the firm's EBITDA to assets ratio over 5-year overlapping periods. $\ln$ (Assets) is the natural log of total assets in \$ millions. Leverage is defined as long-term debt scaled by total assets. Sales growth is defined as the current year's total sales scaled by the previous year's. CAPEX is defined as capital expenditures minus the sales of property, plant, and equipment, with this difference scaled by total assets. $P P E$ is defined as net property, plant, and equipment scaled by total assets. SP dummy is a dummy variable that takes on the value of 1 if the firm is included in the S\&P 500 index in the corresponding year, and zero otherwise. The Inv. (inverted) E-Index is measured as 6 minus the number of specified governance provisions in effect for a given firm-year. T-statistics based on standard errors clustered by both firm and year are reported below the coefficients. *, $* *$, and $* * *$ indicate statistical significance levels of $10 \%, 5 \%$, and $1 \%$, respectively.

We report the impacts of protective provisions on firm value in Table 9. Interaction effects between risk-taking and protective provisions are significantly negative in Column $3-6$. It appears that the negative effect of the P-index is driven by three components in the index: director liability, severance agreements, and golden parachutes. While the interaction effect somewhat reduces risk-taking, the net effect is still positive as $0.045(=-0274+0.0729)$ in the P-index, which is consistent with that in Table 3. Although managers are protected, they do not materially increase firm value through more risk-taking. Hence, we cannot support Hypothesis 3 as corporate governance increases firm value with or without risk-taking. The result is consistent with the study by Croci et al. (2017), who do not support the risk incentive theory of hedging strategy, which argues that managers with high risk incentives bypass hedging strategies to curb upside potential.

Table 9. Protective provision on firm value

\begin{tabular}{|c|c|c|c|c|c|c|}
\hline $\begin{array}{l}\text { Dependent var: } \\
\text { Tobin's Q }\end{array}$ & $\begin{array}{c}(1) \\
\text { Protect = } \\
\text { CompPlan }\end{array}$ & $\begin{array}{c}(2) \\
\text { Protect = } \\
\text { Indem }\end{array}$ & $\begin{array}{c}(3) \\
\text { Protect = } \\
\text { DirLiab }\end{array}$ & $\begin{array}{c}\text { (4) } \\
\text { Protect = } \\
\text { Severance }\end{array}$ & $\begin{array}{c}(5) \\
\text { Protect = } \\
\text { GParachute }\end{array}$ & $\begin{array}{c}(6) \\
\text { Protect = } \\
\text { P-Index }\end{array}$ \\
\hline RISK*Protect & $\begin{array}{l}-0.0290 \\
(-1.08)\end{array}$ & $\begin{array}{l}-0.0301 \\
(-1.50)\end{array}$ & $\begin{array}{c}-0.0487 * * * \\
(-2.86)\end{array}$ & $\begin{array}{c}-0.0401 * * \\
(-2.48)\end{array}$ & $\begin{array}{c}-0.0375^{* *} \\
(-2.29)\end{array}$ & $\begin{array}{c}-0.0274 * * * \\
(-3.80)\end{array}$ \\
\hline RISK & $\begin{array}{c}0.0551 * * \\
(2.66)\end{array}$ & $\begin{array}{c}0.0409 * * \\
(2.72)\end{array}$ & $\begin{array}{c}0.0462 * * * \\
(3.01)\end{array}$ & $\begin{array}{c}0.0439 * * * \\
(2.90)\end{array}$ & $\begin{array}{c}0.0565^{* * * *} \\
\quad(3.40)\end{array}$ & $\begin{array}{c}0.0729 * * * \\
(5.28)\end{array}$ \\
\hline Protect & $\begin{array}{l}0.155 \\
(1.29)\end{array}$ & $\begin{array}{l}0.177 \\
(1.67)\end{array}$ & $\begin{array}{l}0.0589 \\
(0.34)\end{array}$ & $\begin{array}{l}0.146 \\
(1.39)\end{array}$ & $\begin{array}{r}0.0478 \\
(0.58)\end{array}$ & $\begin{array}{r}0.0644 \\
(1.63)\end{array}$ \\
\hline Ln(Assets) & $\begin{array}{c}-0.401 * * * \\
(-5.98)\end{array}$ & $\begin{array}{c}-0.401 * * * \\
(-5.90)\end{array}$ & $\begin{array}{c}-0.400 * * * \\
(-5.93)\end{array}$ & $\begin{array}{c}-0.396 * * * \\
(-5.97)\end{array}$ & $\begin{array}{c}-0.404 * * * \\
(-5.91)\end{array}$ & $\begin{array}{c}-0.402 * * * \\
(-6.04)\end{array}$ \\
\hline Leverage & $\begin{array}{c}-0.603 * * * \\
(-4.32)\end{array}$ & $\begin{array}{c}-0.608 * * * \\
(-4.27)\end{array}$ & $\begin{array}{c}-0.600 * * * \\
(-4.21)\end{array}$ & $\begin{array}{c}-0.610 * * * \\
(-4.27)\end{array}$ & $\begin{array}{c}-0.603 * * * \\
(-4.28)\end{array}$ & $\begin{array}{c}-0.585 * * * \\
(-4.04)\end{array}$ \\
\hline Sales growth & $\begin{array}{c}0.318 * * * \\
(3.00)\end{array}$ & $\begin{array}{c}0.320 * * * \\
(3.11)\end{array}$ & $\begin{array}{c}0.315 * * * \\
(3.03)\end{array}$ & $\begin{array}{c}0.319 * * * \\
(3.07)\end{array}$ & $\begin{array}{c}0.323 * * * \\
(3.13)\end{array}$ & $\begin{array}{c}0.316^{* * *} \\
(2.85)\end{array}$ \\
\hline CAPEX & $\begin{array}{c}2.005^{* *} \\
(2.18)\end{array}$ & $\begin{array}{c}2.025^{* *} \\
(2.32)\end{array}$ & $\begin{array}{c}2.006^{* *} \\
(2.27)\end{array}$ & $\begin{array}{c}2.011 * * \\
(2.29)\end{array}$ & $\begin{array}{c}1.952^{* *} \\
(2.14)\end{array}$ & $\begin{array}{l}1.935^{*} \\
(2.02)\end{array}$ \\
\hline PPE & -0.260 & -0.263 & -0.249 & -0.250 & -0.279 & -0.257 \\
\hline
\end{tabular}




\begin{tabular}{lcccccc} 
& $(-0.60)$ & $(-0.61)$ & $(-0.57)$ & $(-0.58)$ & $(-0.66)$ & $(-0.58)$ \\
S\&P dummy & $0.205^{* * *}$ & $0.203^{* * *}$ & $0.206^{* * *}$ & $0.202^{* * *}$ & $0.206^{* * *}$ & $0.206^{* * *}$ \\
& $(3.11)$ & $(3.10)$ & $(3.13)$ & $(3.08)$ & $(3.14)$ & $(2.99)$ \\
Observations & & & & & & \\
R-squared & 23,048 & 23,048 & 23,048 & 23,048 & 23,048 & 23,048 \\
Firm FE & 0.551 & 0.549 & 0.551 & 0.550 & 0.552 & 0.555 \\
Year FE & YES & YES & YES & YES & YES & YES \\
\hline
\end{tabular}

This table reports OLS regression results. The dependent variable is Tobin's Q, defined as the market value of assets divided by the book value of assets, where the market value of assets equals the book value of assets plus the market value of common stock minus the book value of common stock minus deferred taxes. RISK is the volatility of firm earnings, measured as 100 times the standard deviation of the firm's EBITDA to assets ratio over 5-year overlapping periods. Protect is a dummy variable that equals 1 if a firm-year has the specified protective provision in place, including CompPlan (compensation plans with change in control), Indem (Indemnification contracts), DirLiab (Director Liability), Severance (Severance agreements), GParachute (Golden parachutes), and P-Index (the sum of all protective provision variables). $\ln ($ Assets) is the natural $\log$ of total assets in $\$$ millions. Leverage is defined as long-term debt scaled by total assets. Sales growth is defined as the current year's total sales scaled by the previous year's. CAPEX is defined as capital expenditures minus the sales of property, plant, and equipment, with this difference scaled by total assets. PPE is defined as net property, plant, and equipment scaled by total assets. $S P$ dummy is a dummy variable that takes on the value of 1 if the firm is included in the S\&P 500 index in the corresponding year, and zero otherwise. T-statistics based on standard errors clustered by both firm and year are reported below the coefficients. *, **, and *** indicate statistical significance levels of $10 \%$, 5\%, and $1 \%$, respectively.

\subsection{Efficiency in Capital Allocation}

Table 10 reports regression results on the efficiency of capital investment. Model 1 runs the basic model without any risk-taking interaction terms. Model 2 includes an interaction term that indicates whether a firm is in the upper median with respect to risk-taking (see Eq.(4)). Similarly, Model 3 includes interaction terms that indicate whether a firm is in the middle third or the upper third of the sample with respect to risk-taking (see Eq.(5)). Year and firm fixed effects are included, and standard errors are clustered along both dimensions.

Model 1 of Table 10 reports a positive relationship between investment and value-added growth, with a statistically significant coefficient of 0.0747 and supports Hypothesis 4 that managerial risk-taking increases the efficiency of capital allocation. Consistent with Faccio et al. (2016), the coefficients for CF/Total fixed assets and $\ln (1+$ Age) are positive and negative, respectively.

Table 10. Risk-taking to the efficiency of capital allocation with firm fixed effects

\begin{tabular}{lccc}
\hline $\begin{array}{l}\text { Dependent Variable: } \\
\% \Delta \mathrm{PPE}\end{array}$ & $(1)$ & $(2)$ & $(3)$ \\
\hline GVA & $0.0747^{* * *}$ & $0.0878^{* * *}$ & $0.0977^{* * *}$ \\
& $(16.13)$ & $(14.87)$ & $(15.32)$ \\
GVA*(Upper half risk) & & $-0.0195^{* * *}$ & \\
GVA*(Mid third risk) & & $(-4.25)$ & $-0.0203 * * *$ \\
& & & $-5.84)$ \\
GVA*(Top third risk) & & & $-0.0332 * * *$ \\
Published by Sciedu Press & 241 & ISSN 1923-4023 & E-ISSN 1923-4031
\end{tabular}




$\begin{array}{lccc}\text { No. of employees } & 0.000215 & 0.000212 & 0.000209 \\ & (1.60) & (1.61) & (1.61) \\ \text { CF/TFA } & 0.0199^{* * * *} & 0.0199 * * * & 0.0200^{* * *} \\ & (14.05) & (14.04) & (14.05) \\ \text { Depr.Miss } & -0.167 * * * & -0.167 * * * & -0.166^{* * *} \\ & (-19.95) & (-19.92) & (-19.97) \\ \text { Ln(1+Age) } & -0.0618^{* * *} & -0.0630^{* * *} & -0.0635^{* * *} \\ & (-9.56) & (-9.59) & (-9.64) \\ \text { Constant } & 0.205^{* * *} & 0.202^{* * *} & 0.197 * * * \\ & & (15.10) & (14.58) \\ \text { Observations } & 139,222 & 139,222 & 139,222 \\ \text { R-squared } & 0.223 & 0.223 & 0.223 \\ \text { Firm FE } & \text { YES } & \text { YES } & \text { YES } \\ \text { Year FE } & \text { YES } & \text { YES } & \text { YES }\end{array}$

This table reports OLS regression results. The dependent variable is investment, defined as the ratio of the change in net fixed assets with depreciation added back relative to the current net fixed assets. GVA (growth in value added) is defined as the natural $\log$ of $(1+$ EBIT/lag of EBIT). Upper half risk is a dummy variable that takes the value of 1 if the observation has a risk-taking value greater than the sample median, and zero otherwise. Mid (Top) third risk is a dummy variable that takes the value of 1 if the observation has a risk-taking value within the middle (top) third of the sample, and zero otherwise. No. of employees is the number of employees in thousands. CF/TFA is net income plus depreciation divided by total fixed assets. Depr.Miss is a dummy variable that takes the value of 1 if data for depreciation is missing, and zero otherwise. $\operatorname{Ln}(1+\mathrm{Age})$ is the natural logarithm of $(1+$ years since listing date). T-statistics based on standard errors clustered by both firm and year are reported below the coefficients. *, **, and $* * *$ indicate statistical significance levels of $10 \%, 5 \%$, and $1 \%$, respectively.

Model 2 reports a negative and significant coefficient for the interaction term as $-0.0195, \mathrm{GVA} *($ Upper half risk). While it indicates that firms taking risk beyond the sample median exhibit dampened sensitivity between investment and value added, it does not reverse the positive effects of GVA on risk-taking because the overall effects of GVA at $0.0683(=0.0878-0.0195)$ is still in line with that of Model $1=0.0747$. Model 3 corroborates this assessment. The coefficient for the interaction term GVA*(Mid third risk) is negative and significant, while the coefficient for GVA*(Top third risk) is also negative but to a greater magnitude. However, the overall effects of GVA remain positive as in Model 2. The findings support Hypothesis 4 that the level of managerial risk-taking positively affects the efficiency of capital allocation. Table 11 reports results with industry fixed effects and shows findings similar to those in Table 10.

Table 11. Risk-taking to the efficiency of capital allocation with industry fixed effects

\begin{tabular}{lccc}
\hline $\begin{array}{l}\text { Dependent Variable: } \\
\% \Delta \mathrm{PPE}\end{array}$ & $(1)$ & $(2)$ & $(3)$ \\
\hline & & & \\
GVA & $0.112^{* * *}$ & $0.132^{* * *}$ & $0.142^{* * * *}$ \\
& $(18.20)$ & $(17.62)$ & $(17.83)$ \\
GVA*(Upper half risk) & & $-0.0326 * * *$ & \\
Published by Sciedu Press & 242 & ISSN 1923-4023 & E-ISSN 1923-4031
\end{tabular}


GVA*(Mid third risk)

GVA*(Top third risk)

No. of employees

CF/TFA

Depr.Miss

Ln(1+Age)

Constant

Observations

$\mathrm{R}$-squared

Industry FE

Year FE
$0.000214^{* * *}$

$0.0171 * * *$

$-0.174 * * *$

$-0.0226 * * *$

$(-9.47)$

$0.160 * * *$

137,641

0.153

YES

YES
$(-7.81)$

$$
-0.0281 * * *
$$

$-0.0493 * * *$

$0.000168^{* * *}$

$0.0170 * * *$

$-0.172 * * *$

(-20.11)

$-0.0257 * * *$

$-0.0249 * * *$

(-10.86)

$(-10.51)$

$0.147 * * *$

137,641

137,641

0.154

YES

YES

This table reports OLS regression results. The dependent variable is investment, defined as the ratio of the change in net fixed assets with depreciation added back relative to the current net fixed assets. GVA (growth in value added) is defined as the natural log of (1+EBIT/lag of EBIT). Upper half risk is a dummy variable that takes the value of 1 if the observation has a risk-taking value greater than the sample median, and zero otherwise. Mid (Top) third risk is a dummy variable that takes the value of 1 if the observation has a risk-taking value within the middle (top) third of the sample, and zero otherwise. No. of employees is the number of employees in thousands. CF/TFA is net income plus depreciation divided by total fixed assets. Depr.Miss is a dummy variable that takes the value of 1 if data for depreciation is missing, and zero otherwise. $\operatorname{Ln}(1+\mathrm{Age})$ is the natural logarithm of $(1+$ years since listing date). T-statistics based on standard errors clustered by both firm and year are reported below the coefficients. *, **, and $* * *$ indicate statistical significance levels of $10 \%, 5 \%$, and $1 \%$, respectively.

The results show that while increased managerial risk-taking slightly reduces efficiency in capital allocation, the tests still show that it enhances firm value. This indicates that the merits of risk-taking in the context of corporate investments are captured by contemporaneous growth in value added. On the other hand, it is consistent with the view that value-enhancing risk-taking is characterized by delivering immediate or certain payoffs and by promising corporate investments that are long-term in nature.

\section{Conclusion}

Shareholders, boards, and academics are well aware of the detrimental effects of excess managerial risk-aversion. Managers may forgo profitable projects that they consider too risky in order to protect their private benefits, thereby violating their fiduciary duty to maximize shareholder value. In response, many firms have implemented various incentive-aligning mechanisms to encourage more risk-taking, such as specific corporate governance provisions or executive stock option compensation.

We present evidence that validates such mechanisms. Using a long-period sample of US public firms during 1961-2015 excluding financial firms and utilities, we find that greater managerial risk-taking positively affects firm 
value. Specifically, we find that firms with generally higher levels of risk-taking exhibit this relation, while those with lower levels do not. The findings are steady over several sub-periods and robust with the 2SLS approach.

The result does not show the impacts of corporate governance on firm value through risk-taking. Additionally, we find no evidence of "excessive" risk-taking such that it damages firm value. One possible explanation is that on average, firms are well below their optimal risk-taking levels, and that shareholders would benefit by continuing in their efforts to combat managerial risk-aversion without much concern for risk-taking becoming excessive. This paper also presents evidence that risk-taking is linked to slightly reduced but positive efficiency in capital allocation, suggesting that the value-enhancing nature of risk-taking is characterized as both delivering contemporary payoffs and by promising long-term investment decisions that do not yield immediate returns.

This paper contributes to the literature by providing a deeper understanding on the relation between risk-taking and firm value. Future studies may consider investigating alternative approaches in identifying when and how risk-taking becomes excessive or value-destroying.

\section{References}

Acharya, V. V., Amihud, Y., \& Litov, L. (2008). Creditor rights and corporate risk-taking. Working Paper, New York University.

Bebchuk, L. A., \& Cohen, A. (2005). The costs of entrenched boards. Journal of Financial Economics, 78(2), 409-433.

Bebchuk, L., Cohen, A., \& Ferrell, A. (2009). What matters in corporate governance?. Review of Financial Studies, 22(2), 783-827.

Boubakri, N., Cosset, J., \& Saffar, W. (2013). The role of state and foreign owners in corporate risk-taking: Evidence from privatization. Journal of Financial Economics, 108(3), 641-658.

Byrd, J., Parrino, R., \& Pritsch, G. (1998). Stockholder-manager conflicts and firm value. Financial Analysts Journal, 54(3), 14-30.

Cain, M., \& McKeon, S. (2016). CEO personal risk-taking and corporate policies. Journal of Financial and Quantitative Analysis, 51(1), 139-164.

Chan, Y. R., \& Ma, Y. (2011). Revisiting the risk-taking effect of executive stock options on firm performance. Journal of Business Research, 64, 640-648.

Chatjuthamard, P., Jiraporn, P., \& Lee, S. M. (2021). Does board gender diversity weaken or strengthen executive risk-taking incentives?. Working paper. Retrieved from https://ssrn.com/abstract=3933427

Coles, J., Daniel, N., \& Naveen, L. (2006). Managerial incentives and risk-taking. Journal of Financial Economics, 79(2), 431-468. http://doi.org/10.1016/j.jfineco.2004.09.004

Cremers, M., \& Ferrell, A. (2014). Thirty years of shareholder rights and firm value. Journal of Finance, 69(3), 1167-1196.

Croci, E., Giudice, A., \& Jankensgard, H. (2017). CEO age, risk incentives, and hedging strategy. Financial Management, Fall, 687-716.

Dong, Z., Wang, C., \& Xie, F. (2010). Do executive stock options induce excessive risk taking?. Journal of Banking \& Finance, 34(10), 2518-2529.

Faccio, M., Marchica, M., \& Mura, R. (2016). CEO gender, corporate risk-taking, and the efficiency of capital allocation. Journal of Corporate Finance, 39, 193-209.

Faccio, M., Marchica, M.-T., \& Mura, R. (2011). Large shareholder diversification and corporate risk-taking. Review of Financial Studies, 24(11), 3601-3641.

Giroud, X., \& Mueller, H. M. (2011). Corporate governance, product market competition, and equity prices. Journal of Finance, 66(2), 563-600.

Gompers, P., Ishii, J., \& Metrick, A. (2003). Corporate governance and equity prices. Quarterly Journal of Economics, 118(1), 107-155.

Gormley, T. A., \& Matsah, D. A. (2014). Common errors: How to (and not to) control for unobserved heterogeneity. Review of Financial Studies, 27(2), 617-661. 
Hirshleifer, D., \& Thakor, A. V. (1992). Managerial conservatism, project choice, and debt. Review of Financial Studies, 5(3), 437-470.

Imhof, M. J., \& Seavey, S. E. (2014). Corporate risk-taking, firm value and high levels of managerial earnings forecasts. Advances in Accounting, incorporating Advances in International Accounting, 30, 328-337.

Jensen, M. C., \& Meckling, W. H. (1976). Theory of the firm: Managerial behavior, agency costs and ownership structure. Journal of Financial Economics, 3(4), 305-360.

Jiao, Y. (2010). Stakeholder welfare and firm value. Journal of Banking \& Finance, 34(10), 2549-2561.

John, K., Litov, L., \& Yeung, B. (2008). Corporate governance and risk-taking. Journal of Finance, 63(4), 1679-1728.

King, T.-H. D., \& Wen, M.-M. (2011). Shareholder governance, bondholder governance, and managerial risk-taking. Journal of Banking \& Finance, 35(3), 512-531.

Low, A. (2009). Managerial risk-taking behavior and equity-based compensation. Journal of Financial Economics, 92(3), 470-490.

Mohsni, S., Otchere, I., \& Shahriar, S. (2021). Board gender diversity, firm performance and risk taking in developing countries: The moderating effect of culture. Journal of International Financial Markets, Institutions and Money, 101360. https://doi.org/10.1016/j.intfin.2021.101360

Morck, R., Shleifer, A., \& Vishny, R. W. (1988). Management ownership and market valuation. Journal of Financial Economics, 20, 293-315.

Ongsakul, V., \& Jiraporn, P. (2019). How do independent directors view powerful executive risk-taking incentives? A quasi-natural experiment. Finance Research Letters, 31, 463-470.

Shleifer, A., \& Vishny, R. W. (1997). A survey of corporate governance. Journal of Finance, 52(2), 737-783.

Van Wesep, E. D., \& Wang, S. (2014). The prevention of excess managerial risk taking. Journal of Corporate Finance, 29, 579-593.

Wurgler, J. (2000). Financial markets and the allocation of capital. Journal of Financial Economics, 58(1), 187-214.

\section{Notes}

Note 1. ISS offers corporate governance data in two different channels: the legacy dataset and the recent governance dataset. The legacy dataset provides data from 1990 to 2006 for non-consecutive years. Specifically, data is available for years 1990, 1993, 1995, 1998, 2000, 2002, 2004, 2006. Since the implementation of specific governance provisions are unlikely to change year to year, we follow the literature and impute corporate governance scores for the intermediate years. In other words, we assign an E-Index score for intermediate years equivalent to the most recently available score. We append this dataset with the more recent governance dataset, which provides data for every year between 2007 and 2015, inclusive. The combined governance dataset runs from 1990 to 2015.

Note 2. Although the results in sub-periods are slightly different from those in Table 3, we find that those do not reverse positive relations between risk-taking and firm value. We omit detailed reports to save space here, but those are available upon request.

\section{Copyrights}

Copyright for this article is retained by the author(s), with first publication rights granted to the journal.

This is an open-access article distributed under the terms and conditions of the Creative Commons Attribution license (http://creativecommons.org/licenses/by/4.0/). 